\title{
Exploring Environmental Entrepreneurship: Identity Coupling, Venture Goals, and Stakeholder Incentives
}

\author{
Jeffrey G. York \\ University of Colorado - Boulder \\ Leeds School of Business \\ (303) 807-6027 \\ Jeffrey.york@colorado.edu \\ Isobel O’Neil \\ University of Nottingham \\ Nottingham University Business School \\ Saras D. Sarasvathy \\ University of Virginia \\ Darden Graduate School of Business Administration
}

Forthcoming, Journal of Management Studies

https://www.researchgate.net/publication/295088464

DOI: $10.1111 /$ joms.12198 


\title{
Exploring Environmental Entrepreneurship: Identity Coupling, Venture Goals, and Stakeholder Incentives
}

\begin{abstract}
On the basis of a qualitative study of 25 renewable energy firms, we theorize why and how individuals engage in environmental entrepreneurship, inductively defined as: the use of both commercial and ecological logics to address environmental degradation through the creation of financially profitable organizations, products, services, and markets. Our findings suggest that environmental entrepreneurs: (1) are motivated by identities based in both commercial and ecological logics, (2) prioritize commercial and/or ecological venture goals dependent on the strength and priority of coupling between these two identity types, and (3) approach stakeholders in a broadly inclusive, exclusive, or co-created manner based on identity coupling and goals. These findings contribute to literature streams on hybrid organizing, entrepreneurial identity, and entrepreneurship's potential for resolving environmental degradation.
\end{abstract}

Keywords: Environmental Entrepreneurship, Sustainability, Hybrid Organizations, Institutional Logics, Entrepreneurial Identity, Social Enterprise, Effectuation

Acknowledgements: We are grateful to Mike Russo and three anonymous reviewers for the outstanding guidance and helpful feedback they provided. We would like to thank Tima Bansal, Mike Lenox, Dean Shepherd, Sankaran Venkataraman, Ted Waldron, participants in the $10^{\text {th }}$ Annual NYU/Northeastern Social Entrepreneurship Conference, participants in the $3^{\text {rd }}$ GRONEN Reading Group, and participants in the 2014 Davis Conference on Qualitative Research for their helpful comments on earlier versions of this study. In addition, we thank all of our interview participants for their time and insights. Jeffrey York gratefully acknowledges the financial support of the Vogt Sustainability Research fund and the Shane Faculty Scholar Gift through the Center for Education on Social Responsibility at the Leeds School of Business, University of Colorado Boulder for this research. 


\section{Exploring Environmental Entrepreneurship: Identity Coupling, Venture Goals, and Stakeholder Incentives}

"What the research on social dilemmas demonstrates is a world of possibility rather than necessity. We are neither trapped in inexorable tragedies nor free of moral responsibility for creating and sustaining incentives that facilitate our own achievement of mutually productive outcomes."

- Elinor Ostrom, 1997: 16

Scholars have argued that entrepreneurial action can address a broad array of societal issues (Dacin, Dacin, \& Matear, 2010; Mair \& Marti, 2006; Russo, 2010; Short, Moss, \& Lumpkin, 2009), including degradation of the natural environment (Dean \& McMullen, 2007; Hall, Daneke, \& Lenox, 2010; Muñoz \& Dimov, 2015; Patzelt \& Shepherd, 2011; Shepherd \& Patzelt, 2011; York \& Venkataraman, 2010). Recent organizational theory work has turned attention to hybrid organizations (Battilana \& Dorado, 2010; Battilana, Sengul, Pache, \& Model, 2015; Hockerts, 2015; Jay, 2013), and specifically, social enterprises (Battiliana, Lee, Walker, \& Dorsey, 2012; Smith, Gonin, \& Besharov, 2013), as unique organizational forms for addressing social and environmental problems . Such organizations are posited to differ from traditional ventures because the entrepreneurs who initiate them are motivated by compassion, rather than wealth creation (Grimes, McMullen, Vogus, \& Miller, 2013; Miller, Grimes, McMullen, \& Vogus, 2012) and the ventures combine social welfare and commercial institutional logics within the organization (Battilana \& Lee, 2014; Besharov \& Smith, 2014; Haigh \& Hoffman, 2012; Smith et al., 2013).

The literature on hybrid organizations and social enterprise offers important insights into how entrepreneurs tackle social issues, but it has paid relatively little attention to explicating how hybrid organizations may address environmental 
sustainability (but see Haigh \& Hoffman, 2012). For example, scholars suggest that addressing human-induced climate change will require massive shifts across economic, organizational, and transnational boundaries (Ansari, Gray, \& Wijen, 2011; Ansari, Wijen, \& Gray, 2013; Hiatt, Grandy, \& Lee, 2015; Howard-Grenville, Buckle, Hoskins, $\&$ George, 2014; IPCC, 2014), but the role of entrepreneurs in such change has received little investigation. Interestingly, political economists have suggested that small-scale enterprises are necessary complements to political change in addressing climate change (Ostrom, 2010, 2012), but make no link to entrepreneurial action. While the concept of environmental entrepreneurs, who create hybrid organizations fostering simultaneous "economic and ecological benefits" has been theoretically discussed (Dean \& McMullen, 2007; Lenox \& York, 2012: 70), little is known about the creation of such ventures. In this study we sought to understand two interrelated research questions: Why and how do individuals engage in environmental entrepreneurship? These questions are critical, because as Tracey and Phillips (2007: 267) assert, "conflict between social and commercial priorities" is a central challenge of hybrid organizations; environmental entrepreneurs often face specific challenges (Pacheco, Dean, \& Payne, 2010; Russo, 2001), linked to a broader conflict between commercial and ecological logics (Frederick, 1999; Jay, 2013; Lee \& Lounsbury, 2015; Mars \& Lounsbury, 2009; York, Hargrave, \& Pacheco, 2015). While the literature has posited that environmental entrepreneurs are driven by a desire to address environmental degradation of the natural environment (Kuckertz \& Wagner, 2010; Patzelt \& Shepherd, 2011; Shepherd \& Patzelt, 2011), little explanation has been given as to the source and consequences of such motivations. To address our research questions, we engaged in an inductive field study of 25 
environmental entrepreneurs who were establishing, or had established, ventures primarily in renewable energy, but also in green building and energy efficiency. These ventures help to reduce reliance on pollution-intensive forms of energy production (Russo, 2003), and thus address human-induced climate change (Ansari et al., 2011; IPCC, 2011, 2014). Yet, these sectors also demand economic profitability, necessitating the creation of hybrid organizations. Following the tenets of grounded theory (Glaser \& Strauss, 1967; Locke, 2001) to gather and analyze our data, we came to recognize the importance of the founder's identity for motivating environmental entrepreneurship.

It has been suggested that an entrepreneur's "passion” for a particular entrepreneurial role, such as founder, developer or inventor, gives coherence to the emerging venture (Cardon, Wincent, Singh, \& Drnovsek, 2009; Murnieks, Mosakowski, \& Cardon, 2012). Fauchart \& Gruber (2011) explicated a typology of founder social identities (i.e. Darwinians, Communitarians, and Missionaries) and explored the organizational imprinting implications of each identity. While the idea that multiple identities can play a role in driving entrepreneurship has been discussed (see Wry \& York, 2015), empirical research has yet to provide much insight into hybrid founder identities. Fauchart and Gruber briefly state that a hybrid identity pertains to "founders who combine elements of the Communitarian and Darwinian identity" and suggest that it will foster "strategic decisions based on meanings associated with one of the identities, or that a particular decision combines the meanings of both identities" (2011: 949). Extending beyond this, our findings begin to specifically explain how identity is implicated in motivating individuals to engage in environmental entrepreneurship. Specifically, our inductive research suggests that environmental entrepreneurs are motivated not only by a "pro- 
social identity" (e.g. Austin, Stevenson, \& Wei-Skillern, 2006; Fauchart \& Gruber, 2011), but also by the opportunity to couple competing identities aligned with commercial and ecological logics. Our findings suggest this coupling between salient identities associated with each logic is a critical explanation of why individuals become environmental entrepreneurs.

As we advanced our data analysis, we discovered that the strength and priority of coupling between identities within individual entrepreneurs raised new questions. Given the widely perceived tension between commercial and ecological logics, how do such environmental entrepreneurs delineate goals and recruit stakeholders? This inductively derived link between identity, goals and stakeholders became the focus of our ongoing analysis. Stakeholders, defined as individuals who dedicate their own resources to cocreate new ventures with entrepreneurs (Sarasvathy, 2001; Sarasvathy, 2008; Venkataraman, 2002), are central to the development of all new ventures (Aldrich, 1999; Aldrich \& Fiol, 1994; Suchman, 1995). However, the hybrid organization literature has largely focused on conflict between stakeholders resulting from their subscription to conflicting logics (Pache \& Santos, 2013; Pache \& Santos, 2010). In contrast, we found that environmental entrepreneurs, dependent on their identity coupling, did (or did not) find ways to bring stakeholders from both commercial and ecological perspectives on board (Pacheco et al., 2010; Schlange, 2009).

Surprisingly, environmental entrepreneurs with an ecological dominant identity took a more exclusionary approach towards stakeholders. In contrast, those with a commercial dominant identity were open to stakeholders associated with either commercial or ecological logics. However, entrepreneurs with a blended identity - who attributed equal 
weight to ecological and commercial goals - created ventures that enabled self-selection by all stakeholders. These findings suggest links between hybrid organizations, entrepreneurial identity, and small-scale approaches to addressing environmental problems.

\section{THEORETICAL BACKGROUND}

Scholars have become increasingly interested in how entrepreneurship can foster non-economic value. For example, social entrepreneurship is a growing phenomenon that has captured the attention of organizational scholars (Dacin, Dacin, \& Tracey, 2011; Dacin et al., 2010; Grimes et al., 2013; Mair \& Martí, 2006; Short et al., 2009; Waldron, Fisher, \& Pfarrer, 2016). Social entrepreneurs are posited to differ from traditional entrepreneurs as they address social problems through economically sustainable business models (Battilana \& Dorado, 2010; Mair \& Marti, 2006; Miller et al., 2012; Moss, et al., 2011; Tracey et al., 2011). As such, the organizations created by social entrepreneurs can be understood as "hybrid organizations" combining social welfare and commercial logics (Battilana \& Dorado, 2010; Battilana \& Lee, 2014; Battiliana et al., 2012). This study focuses on environmental entrepreneurship as a type of hybrid organizing that combines the ecological logic of preservation and protection of the natural environment with a commercial logic of economic efficiency and profits (Dean \& McMullen, 2007;

Frederick, 1999; Lenox \& York, 2012; Shepherd \& Patzelt, 2011; York et al., 2015).

\section{Environmental Entrepreneurship}

The literature on social, environmental, and hybrid entrepreneurs has jointly focused on two questions: (1) how are such entrepreneurs different from "traditional" entrepreneurs and (2) what are the implications of blending social welfare and 
commercial logics and goals within organizations? Regarding the former, research has differentiated the motivations of social entrepreneurs (Dacin et al., 2010; Miller et al., 2012; Short et al., 2009). A primary assertion of this literature is that such entrepreneurs differ in their motivations for initiating a venture compared to traditional entrepreneurs due to their greater compassion for the suffering of others (Grimes et al., 2013; Miller et al., 2012). Similarly, environmental entrepreneurs have been posited to be different due to their pursuit of ecological, rather than economic, gains (Schlange, 2006).

For example, Kuckertz and Wagner (2010) found business experience significantly reduced individuals' desire to foster environmental sustainability through entrepreneurship. Patzelt and Shepherd (2011) theorize entrepreneurs are more likely to discover sustainability-related opportunities when they perceive the natural environment as threatened, and they have a greater sense of altruism. However, these insights tell us little of why environmental entrepreneurs create for-profit ventures.

Environmental entrepreneurs are inherently implicated in hybrid organizing, because incompatible institutional logics, defined as shared meaning systems that confer legitimacy upon particular goals and practices (Thornton, Ocasio, \& Lounsbury, 2012), are pursued within an organization. From a hybrid organizing view, environmental entrepreneurs combine ecological and commercial logics that rationalize conflicting goals and practices (Battilana \& Lee, 2014; Besharov \& Smith, 2014). The ecological logic prioritizes acting to address environmental problems while the commercial logic valorizes economic efficiency and profits (Mars \& Lounsbury, 2009; York et al., 2015). However, studies of hybrid organizing have shown combining conflicting logics and goals within an organization is challenging (e.g. Battilana \& Dorado, 2010; Battilana \& 
Lee, 2014; Pache \& Santos, 2013; Pache \& Santos, 2010). This observation led Tracey and Phillips (2007: 267) to assert that "conflict between social and commercial priorities is a central characteristic of social entrepreneurship."

This assertion is largely supported by the literature on environmental entrepreneurship. Hockerts and Wustenhagen (2010) point out that start-ups are more likely than incumbent firms to enter environmentally relevant sectors; similarly York \& Lenox (2014) find environmental social norms and social movements influence start-up entry into green building, but not incumbent entry. Incongruity between ecological and commercial logics is highlighted in studies at both the macro (Pacheco \& Dean, 2015; Pacheco et al., 2010; Pacheco, York, \& Hargrave, 2014; York et al., 2015) and micro level (O'Neil \& Ucbasaran, 2016; Schaltegger \& Wagner, 2011; Shepherd, Patzelt, \& Baron, 2013). Recent work (Wry \& York, 2015) posits that understanding why and how entrepreneurs address such tensions can be extended through identity theory (Stryker, 2000; Stryker \& Burke, 2000).

\section{Identity Theory and Entrepreneurship}

Research in social psychology suggests that identity plays an important role in shaping behavior and motivating action (see Stets \& Burke, 2000 for a review). Identities are associated with culturally defined social roles that comprise the set of named categories that people learn to apply to themselves and others (Burke, 2004: 9). Each identity carries a set of behavioral expectations valuing certain behaviors that individuals are expected to adhere to in a role (Mead, 1934; Stryker, 1980; Stryker \& Burke, 2000). Identities are strongly motivational. Acting in accordance with their behavioral standards verifies important self-conceptions, leading to positive affect and self-esteem; discrepant 
acts are associated with negative emotions Because identities are embedded in social groups, identity-consistent behavior elicits positive reactions from valued others while inconsistency brings derision and scorn (Stryker \& Burke, 2000).

When an actor has a salient entrepreneurial identity, they are motivated to engage in venture creation to validate an important self-conception (Cardon et al., 2009; Hoang \& Gimeno, 2010; Murnieks \& Mosakowski, 2006; Murnieks et al., 2012). Scholars suggest that the behavioral expectations of the entrepreneurial identity are not limited to profit-seeking and may include actions such as innovation, dynamism, perseverance, and risk-taking (Hoang \& Gimeno, 2010; Murnieks \& Mosakowski, 2006). Entrepreneurs may identify with a specific aspect of the venture creation process, such as inventing, founding, and developing, (Cardon et al., 2009) or with the goals of their firm (Fauchart \& Gruber, 2011; Hiatt, Sine, \& Tolbert, 2009; Lounsbury \& Glynn, 2001; Navis \& Glynn, 2011). The process and outcomes of entrepreneurial action have been shown to vary in line with the founders' particular identities (Fauchart \& Gruber, 2011; Powell \& Baker, 2014).

Theoretical work on social enterprise has argued for the inclusion of identitybased explorations (e.g. Dacin et al., 2011; Simms \& Robinson, 2009; Wry \& York, 2015). However, we entered the field in 2007 devoid of such knowledge. Rather, identity as the explanation of why and how entrepreneurs engage in environmental entrepreneurship emerged over time through our fieldwork and analysis.

\section{METHODS AND DATA}

We began our field research on environmental entrepreneurs by focusing on renewable energy, defined as energy sources that utilize limited or no nonrenewable 
resources and/or create significantly less waste than traditional energy sources (Energy Information Administration, 2007; United States International Trade Commission, 2005). By replacing or supplementing current energy sources, such as coal or oil, which emit a large proportion of human-produced $\mathrm{CO}_{2}$, increased use of renewable energy can reduce the severity of human-induced global warming and climate change (IPCC, 2011, 2013). In other words, the renewable energy sector, via the creation of less resource-intensive, less wasteful energy, is concerned with providing an inherent ecological benefit. During our field interviews, we came to also include one firm involved in energy efficiency and two firms involved in green building, as each combined ecological and commercial logics and added diversity to our sample.

These sectors matched our criteria of theoretical relevance (Eisenhardt \& Graebner, 2007) because we sought environmental entrepreneurship firms combining ecological (the displacement of carbon emitting energy sources) and commercial (profitability and financial sustainability) logics and goals. While renewable energy has grown significantly in recent years, it was far from certain in 2007, when our fieldwork began, that it was a viable opportunity. For example, during the time period of our data collection (2007-2010), and even today, the wind energy sector faced significant uncertainty due to technical, economic, and political circumstances (Vasi, 2011). Renewable energy's ability to economically compete with fossil fuel-based sources has remained questionable as illustrated by the sector's dependence on the U.S. federal production tax credit (Bolinger, 2010). Indeed, as illustrated in Table 1 of our original sample, only 14 of 25 firms are still operating as of 2015. During our field work the 
renewable energy sector was a nascent sector characterized by growth and investment, but, importantly, was still fraught with competing ecological and commercial logics.

\section{Participant Sampling Procedure}

We deployed the principles of theoretical sampling to select participants on the basis of appropriateness, rather than representativeness (Eisenhardt \& Graebner, 2007; Glaser \& Strauss, 1967). Three sources were used to identify suitable participants:

Sample One. Our first source was a U.S. business school's "Renewable Energy Forum" (Fall, 2007). The first author initiated contact with five renewable energy entrepreneurs. It was during these interviews that the variety of values and founder identities discussed in entrepreneurs' accounts was first recognized. Following theoretical sampling (Glaser \& Strauss, 1967), our next step was to formalize a sampling criteria for other participants. The criteria centered on selecting founders from firms with the following characteristics:

1) For-profit ventures; as we were concerned with hybrid organizing, we sought environmental entrepreneurs behind commercial ventures which would also offer ecological benefit through renewable (solar, wind, biomass, geothermal, hydrogen, biodiesel, etc.) energy, either directly or through technology innovation in the production of renewable energy or enhanced energy efficiency or green building.

2) Ventures where the founder remained an active member of the management team

3) Ventures where the founder was active in seeking stakeholders such as investors, customers, suppliers, and/or partnerships with corporations, governmental organizations, and/or NGOs

Overall, we believe our criteria ensured requisite variation (e.g. age, firm's principal activities - see Table 1) while ensuring our phenomena of interest were "transparently observable" (Pettigrew, 1990).

Sample Two. Our second source of participants was the Washington International Renewable Energy Conference (WIREC) (Washington D.C, Spring 2008). We selected 
27 firms to contact based on the above criteria. Of these, six founders agreed to be interviewed at WIREC. During the conference we contacted an additional 10 firms who were interviewed later over the telephone. At this stage, we began to note key differences regarding how founders: (1) spoke about their identity as a driver for launching their venture, (2) described goals for the venture, and (3) approached stakeholders. Consistent with a tenet of grounded theory that "data collection is controlled by the emerging theory" (Glaser \& Strauss, 1967:45), we extended our data collection to recruit a final set of participants and to gather additional materials to enhance triangulation.

Sample Three. Contacts from the first author's expanding network of environmental entrepreneurs put us in touch with our final set of four participants. The first author's knowledge of the sector, our previous experience of interviewing entrepreneurs, and our ongoing data analysis assisted our recognition of "category saturation" (Goulding, 2002). After stage three, we were satisfied that we had captured adequate novel insights from our participants to provide fresh understandings with regards to why and how environmental entrepreneurs founded their firms. The final number of participating founders was 25 (five from the business school forum, 16 from WIREC, four from networks). Table 1 provides details of the participants and lists the names of any individuals mentioned. All individual and firm names and details have been replaced to ensure privacy.

Insert Table 1 about here

\section{Data Sources}

We triangulated our findings across three data sources: 
Founder Interviews The first author conducted 38 interviews with the founders of the 25 participant ventures. The interviewees were told simply that we were interested in exploring entrepreneurship in their sector. All interviewees were guaranteed anonymity and agreed to be recorded; the interviews were transcribed verbatim. Interviews lasted between 40 minutes and 1 hour 30 minutes. The interviews were semi-structured using a protocol to ensure greater consistency across all interviews. As it was our aim to gather vivid accounts of our participants' experiences, we took care to ensure that our questions were open-ended and focused on situations and activities in their worlds (Gioia, Corley, \& Hamilton, 2013; Kvale, 1983). These interviews took place over an extended period of time (late 2007 until 2010), providing us with the opportunity to review questions iteratively based on our reflections of the insights elicited and our tentative analysis. An example of an interview protocol is included in Appendix 1. These interviews totaled 426 transcribed, single-spaced pages.

Stakeholder Interviews. Over the course of our data collection we noted that our participants differed in terms of stakeholder engagement; specifically in terms of how they had set about offering stakeholder incentives. Thus, we felt it was necessary to capture insights from stakeholders to probe their engagement with the ventures. While this was not initially part of our research design, our interviews with stakeholders provided insight into what incentivized their involvement with the firm. A total of eight stakeholders were included in our research. We were put in touch with these individuals via the entrepreneurs and acknowledge that our access was somewhat limited. Interviews were recorded and transcribed verbatim, totaling 123 pages. 
Documents. At the time of initial interviews, we gathered additional documentation that was either provided directly by firms (e.g. business plans, marketing documents) or publicly available (e.g. on websites). In addition, we utilized historic website records from the "wayback machine" tool on the Internet archive (archive.org), to collect data on as many firms as we could (four appeared to have never had a web presence - see Table 1). These data enabled us to triangulate our interview data, creating insight into how the founders spoke about themselves (via bios), how they presented their venture's goals, and how they tried to incentivize stakeholders (e.g. employees via "work for us" sections). These data resulted in 431 single-spaced pages.

\section{Data Coding and Analysis}

Our research design evolved iteratively by following the principles of grounded theory (Glaser \& Strauss, 1967; Locke, 2001). Throughout, we followed Van Maanen and colleagues' rationale for theorizing: "there is a back-and-forth character in which concepts, conjectures and data are in continuous interplay... allowing for a logic of discovery” (Van Maanen, Sørensen, \& Mitchell, 2007:1146). Our analysis began during the interviewing process (Charmaz, 2006). In accordance with the grounded theory approach, we simultaneously gathered data and engaged in the process of exploring salient theoretical categories. Our goal throughout was to uncover theoretical constructs to explain why and how environmental entrepreneurship ventures are founded. In this way, we began to discover the linkages described below between theories of hybrid organizing, identity, and effectuation.

As mentioned above, once we were satisfied that we had reached theoretical saturation and that no new insights were emerging from our interviews, we moved to a 
more formal stage involving scrutinizing our interpretations and emergent categories. Central to grounded theory is the constant comparative approach (Glaser \& Strauss, 1967). Thus, we set about coding and analysis concurrently by labeling and sorting fragments of text from the transcripts (coding) while interpreting these fragments' meaning (Locke, 2001). In practice there were three distinctive stages:

Stage One. We first constructed a database using NVivo qualitative analysis software to bring together field notes, interview transcriptions, and any collected documentation and memos related to the particular founder or stakeholder. The first two authors worked independently on the data so that each coder could inductively compile a tentative set of first order codes. The second author began coding after all data collection was complete, was based in a different country, and only had brief, general conversations with the first author prior to coding. The third author did not engage in coding, and thus remained the "outsider" to help ensure the trustworthiness of our findings based on the evidence presented (Gioia et al., 2013; Strauss \& Corbin, 1994). Following the coding of this sample, the first and second authors reviewed each other's coding to compare and contrast with the labels, descriptions and excerpts produced by their own coding efforts. Table 2 provides an example, discussed below, of some initial differences in first order codes, and their eventual convergence.

Insert Table 2 about here 
For the commercial aspect of a founder's identity, the second author had coded to a set of four first order $\operatorname{codes}^{1}$, whereas the first author had independently coded such data to a broader code "economic motivation." Discussions and debate ensued and eventually these five separate first order codes were collapsed into the final set of three first order codes for the Commercial Dominant identity (see Table 2). Similarly, for Blended Identity, the first author had deployed the code "mixed motivation" but the second author had produced two codes ${ }^{2}$. Again, through debate and discussion, we agreed upon a set of three codes. Building upon our discussions with the third author, we then compared our coding in relation to more environmental drivers resulting in two first order codes in relation to Ecological Dominant Identity. This process was followed for all 20 of the first order codes in Table 3.

\section{Insert Table 3 about here}

Stage Two. Stage two was a more deductive, theoretically driven stage involving in-depth exploration of literature on entrepreneurial identity (e.g. Hoang \& Gimeno, 2010; Fauchart \& Gruber, 2011), hybrid organizing (e.g. Battilana \& Lee, 2014) and effectuation (Sarasvathy, 2001; Sarasvathy \& Dew, 2005b). To be clear, following exemplars of grounded theory, we did not seek independence as we moved to second order themes. Rather, we collaborated and debated "..firmly in the theoretical realm, asking whether the emerging themes suggest(ed) concepts that might help us describe and explain the phenomena we are observing" (Gioia et al., 2013: 20). We thus moved from

\footnotetext{
${ }^{1}$ Namely: "Deriving enjoyment from profit-making activities", "Explicit business person reference", "Renewable energy as profitable opportunity", and "Coveting personal wealth accrual".

${ }^{2}$ Namely: "Values-Business Ethos Links" and "View of business as valid form of activism".
} 
"inductive" to "abductive" research, with the data and existing theory considered in tandem (Alvesson \& Kärreman, 2007; Gioia et al., 2013). Throughout the creation of the second order codes, the first two authors sought to explain, document, and verify our findings with the "outsider" third author.

During this stage we paid particular attention to differences in accounts, not only from case to case but within each participant's accounts. Building on insights derived during first order coding, we recognized that the environmental entrepreneurs were expressing different emphasis on the salience of each identity, and hence there was variation in the extent of coupling between commercial and ecological identities. Our analysis and discussion also advanced our appreciation of the link between ideas in the effectuation literature and our findings that hybrid founder identity influenced goals and approaches to stakeholders. The relationship between the codes and second order themes is presented in Table 3 .

Stage Three. As we moved between analyzing the data and creating theoretical explanations for the patterns we perceived, we created multiple iterative versions of the grounded theory presented below. These early drafts were developed into working papers and presented to colleagues, as well as a subset of study participants, for multiple rounds of critical feedback. This process helped us to finalize our three aggregate theoretical dimensions: (1) those that show founder hybrid identity coupling, (2) those that signal venture goals that emerged from the various categories of hybrid identities, and (3) those translating how identities and goals influenced stakeholder incentivizing as represented in Table 3. These findings are discussed in depth below, with quotes followed by the participant's name, or another data source. 


\section{FINDINGS}

Our inductive analysis soon signaled that universally across our founder interviews, the entrepreneurs coupled together elements of commercial and ecological logics to account for their motivation for starting the venture. This insight led us to conclude that for each founder, identities linked to both logics were salient to the venturing process. Thus, each entrepreneur could be said to hold a hybrid identity that coupled elements of potentially conflicting logics within the self. As we investigated further, we came to understand that the informants fell into three categories according to the priority and strength of coupling between these identities. For some there was a loose coupling with one identity dominating; for others both identities were tightly integrated and blended, and thus, neither dominated. As we discuss below, this insight drove our typology of hybrid founder identities as: 1) Commercial Dominant, 2) Ecological Dominant, or 3) Blended.

With a clearer picture as to why environmental entrepreneurs initiated their ventures based on our identity typology, we set about unpacking how these identities impacted the process of creating the new venture. First, we uncovered key differences in the link between the identity type and the venture goals articulated. Second, as our analysis triangulated through additional documents, website materials and stakeholder interviews, we uncovered novel insights into the impact of founder identities and resultant venture goals on how entrepreneurs approach incentivizing potential stakeholders. Below we detail these impacts for each identity type. Figure 1 illustrates our typology and range, as well as modeling the implications of each identity type for venture goals and stakeholder incentivizing. Table 4 provides further quotes to support 
our categorization and Table 5 provides further details on the venture goals and stakeholder approached resulting from each identity.

\begin{tabular}{|c|}
\hline Insert Figure 1 about here \\
\hline Insert Table 4 about here \\
\hline Insert Table 5 about here \\
\hline
\end{tabular}

\section{Commercial Dominant Identity Coupling}

Entrepreneurs in our first category portrayed their environmental entrepreneur identity as dominated by a commercial logic, focusing on exploiting commercial opportunity. For example, Jeff Fielding emphasized, “we weren't a bunch of environmentalists... it was more of a business school rationale of, hey here's a business opportunity." Indeed, the business opportunity resulted from a year-long consultancy project for a gasification supplier during which the founders:

...discovered the world of renewable energy and became intrigued with the technologies and challenges of offering clean options to industrial customers... The idea for [Biomass2] was born. (Biomass2 website)

However, such insights suggested that, alongside typical talk of being motivated by making a financial return, these entrepreneurs emphasized, as a secondary consideration, a personal commitment to the importance of "clean" or "good" renewable energies. Even the most commercially oriented founders also exhibited a weaker, but salient, identity linked to an ecological logic. For instance:

I just get jazzed about the opportunities... I want to help people, but I also want to make this thing as big as fast as possible. You know, you talk about energy mark- 
ups, this is the mother of all mark-ups... you'd be essentially unlocking many billion dollars of money that they're spending today on kerosene and diesel, that are bad, that they could be spending on something good [Biomass] ...So there are multiple motivations... I'm just a filthy capitalist and want to make killer money... I just try to make that work as fast as possible. But's that's OK...it isn't like you're starting something that's stealing babies or whatever. (Colin Stroud)

In a similar vein, one founder told us "I' $m$ a die-hard entrepreneur and that is just the way it is" but he then expressed that:

I was promoting [solar energy] and also not making any money because I was putting too much time into it. But an important part of my life and background, was being involved and making those kind of contributions [to solar energy]. (David Bonnet)

David primarily expressed a commercial personal focus, but his comments also signaled how important it was to him to reflect his own commitment to solar energy and its attendant ecological goals. This was further explained on his firm's website which stated "...we believe that converting home energy systems to solar greatly benefits our planet. Converting to a solar water heating system can save nearly one third of the energy consumption in most homes." (Thermal Solar, Website)

For these cases, we found that a "Darwinian" identity (Fauchart \& Gruber, 2011) was articulated, i.e. a desire to generate personal wealth, but secondary to this a “missionary" identity was also portrayed (Fauchart \& Gruber, 2011) i.e. their personal commitment to create ecological benefits. While each identity was salient in interviews with these founders, the identities were loosely coupled, in that these entrepreneurs did not present them as integrated and tightly blended, but rather, as parallel parts of themselves. Their primary role was to focus on commercial profits and viability; ecological outcomes were ancillary benefits. We label this combination of founder identities Commercial Dominant, defined as: desire for wealth and status as a founder 
(commercial) but also showing commitment to preserving the natural environment (ecological).

Commercial Goals - Inclusive Incentivizing. Commercial dominant founders were clear that their primary goal was to generate wealth. Timothy Pratt described his commercial goal:

[Our mission is] to turn a profit making biodiesel. I mean you obviously have to be able to make a living. It was difficult. When I decided to, I was like, "Can I really do this? Can I make a living making biodiesel? Can I pay my bills?" Like, what's going on here? But, yeah, it's feasible. (Timothy Pratt)

As exemplified in these types of comments, this group viewed environmental entrepreneurship as creating an economically profitable firm that might be sold at a later date:

Once everybody's got enough engineering information about that project - that we know how much money it will make and how much it will cost and how long it takes, and we've reduced the uncertainty a lot - we want to sell the company to somebody else, like a big wind project development company. My intention is to get it going, flip it, and get out of it. (Lorenzo Cruz)

With a clear goal to grow a feasible, profitable company quickly, the accounts soon revealed a basic economic approach to incentivizing stakeholders. For example, Calvin Mayer told us:

It's kind of crude but I always told my guys, you know "during the 1849 gold rush, a few people made a lot of money at discovering gold but the guy who made shovels made a lot of money". And so we're making shovels. (Calvin Mayer).

Another entrepreneur, Timothy Pratt spoke about a strategy he uses to source waste oil for his biodiesel production. He described approaching potential suppliers as creating an economic incentive for them to help him:

[I] knock on the back door. Tell them that I make fuel out of it. I ask them if they have any diesel vehicles. And I can give them five gallons or whatever if they want to try some. And some... there's actually one Chinese restaurant in (town). The 
guy, he wants to take me to China, make millions. "We (will) go to China. We (will) make millions." He always says that to me. (Timothy Pratt)

The entrepreneur's dominant commercial identity and their mission to generate wealth through a profitable firm clearly influenced their approach to incentivizing potential stakeholders. While there was no particular drive to actively pursue ecologically oriented stakeholders, they did welcome all stakeholders:

And, you know, the appeal... we kind of tell a different story depending on somebody's reason for doing it, you know. Some people had an environmental reason. Say, "Hey, here's a renewable energy company. I want to be a part of that." "Well, we do renewable energy. Come on board." (Jeff Fielding)

Fielding realized that the ecological side of his firm is an important selling point, and was happy to leverage it to help obtain his commercial goals. This inclusive approach to how a firm is presented to others was also clearly expressed on Lorenzo Cruz' website: [Marine Energy2] has invented and is patenting two new in-stream hydrokinetic turbines based on radical innovations in other industries. These new turbines will revolutionize renewable in-stream power generation and make it cost-effective around the world... We are committed to the development of sustainable communities supported by renewable hydrokinetic energy. Water resources are almost always a major concern to their local communities. They cannot be developed and sustained above the micro-scale unless there is local support and capability. Our business philosophy is to provide a cost-effective technology and training and consultation in how to apply it with community support. This drives our commitment to adaptability, transparency and building trust with our partners and customers. (Marine Energy2 Website)

Our analysis suggested that these entrepreneurs were open to a wide range of stakeholder commitments. Surprisingly, we found this was not the case in our next group.

\section{Ecological Dominant Identity Coupling}

The second category of hybrid founder identity was uncovered in accounts that were dominated by motivation to tackle environmental problems. For example, Raymond Graybill told us how he had been obsessed with protecting local flora and fauna since the 
age of 15 and had devoted 20 years of his life to environmental conservation. However, Graybill also had a "knack for" energy and solar power and had worked as research scientist in that area. When explaining why he founded a solar firm, Raymond stated "...to make it (solar power) a true alternative... make it a commercial product."

Raymond's stakeholders noted this regarding his ecological dominant identity:

I know from having long talks with him [Raymond] that his motivations go very deep into a core belief system about our responsibility as citizens and that, as just another species passing through the planet, we've got to do the right thing. (Russ Wood, Stakeholder of Raymond Graybill)

Beyond their ecological identity, this group of founders also appreciated the commercial value of entrepreneurship, but the commercial aspects of the firm were a means to reinforce their ecological identity. For example, Mitchell Jenkins emphasized providing environmental alternatives by running his own business:

You know that sincere motivation in me is to come up with some [environmental] solution and just play my own small role in providing a solution...I can't live my life just thinking that I just perpetuate the status quo. I can't live like that. (Mitchell Jenkins)

Another exemplar of this category is Carlos Cartagena whose website bio explained:

Early in his career, [Cartagena] worked to promote solar energy as a media specialist for the U.S. Department of Energy during the Carter Administration. While serving as the national media director for Greenpeace USA during the 1980 s, he saw how renewable energy could help solve the world's energy and environmental challenges. (Solar1 Website)

In conversation, Cartagena told us that after having spent years expending effort to "reduce carbon emissions and energy costs" he came to realize that the time had come to enter the world of business:

I mean, the philanthropic approach was great. It's seeding it as pilot projects, as educational, as getting governments involved, communities involved. It all worked well. Then the next need, the crying need was, hey, companies have to do this because... there's a lot more private capital in the world than there is 
philanthropic money. It needs to be commercialized. It needs to be commercially sustainable. (Carlos Cartagena)

Identity for this group was grounded in environmentalist backgrounds and notfor-profit experiences; however, these founders also expressed how it was now incumbent upon them to challenge the status quo through entrepreneurship. In sum, a personal commitment to protecting the natural environment and openness to commercial means brought about the pursuit of entrepreneurship for what we label the Ecological Dominant identity defined as: a personal commitment to preserve and protect the natural environment (ecological) but utilizing commercial activities to achieve this goal (commercial).

Ecological Goals - Exclusive Incentivizing. In contrast to the commercial dominant group, ecological dominant founders began were enmeshed in a deep understanding of the negative environmental impacts of business; they sought to offer an alternative. Their most salient founder identity, linked to valuing protection of the earth's natural resources, lies at the heart of their venture's goal. For instance, Joseph Albert said:

The mission is to reduce the waste of energy, be more careful with all the resources we have, and try, for the coming generation, to prepare something, which they still can work with. So we're not taking everything away and just living like kings, just being careful with everything you're doing. (Joseph Albert)

These founders often alluded to their goals clearly in public forums. For example:

We assume stewardship responsibility for the earth's resources and people; our community, organizational and personal relationships; and the quality of our products and services. (Marine Energy1, Website)

Once we noted that this group's founders were embedding their ecological dominant identity firmly within the venture's goals, our analysis turned to how they set 
about incentivizing stakeholders. These founders often had histories of environmental campaigning and worked previously in non-profits. As such, this group focused on recruiting people who shared their ecological goals, and were not too "corporate":

We've brought a number of people on board, particularly young people coming out of school who don't want to jump in the middle of a corporate environment. So, people who are interested in kind of a green arena - renewable energy or green technology and so forth. We're a pretty visible company, so people see it as an opportunity to get engaged in something that might be pretty exciting for them. (Noel Upton)

Across all of our categories, we were told that stakeholders with similar values were keen to get involved in ventures and entrepreneurs. However, when ecological dominant entrepreneurs encountered those with different values, they often reacted negatively. For example, Aaron Rawson told us he was once interviewing a candidate who said his main goal was "to make a lot of money." When asked how he would do that, the candidate replied "I would hedge your portfolio with oil." Aaron revealed:

He was not employed. When we hire people, you know, we also tell them that probably in an investment bank, where they have no mandate for investing with maybe a smaller profit and a higher social return, you'd probably make much more money. And nobody's starving, but... if it's just about the money, then you're probably in the wrong spot.

Although a strong ecological dominant identity was extremely inspiring for some stakeholders, it also led entrepreneurs to close doors to others. This exclusionary approach, in which only stakeholders who shared the ecological goals of the firm were involved, was typical across this group. For example, Raymond Graybill stated that he was focused on:

... the environment community...we want to be the guy when you say... "Look, we want to build this solar project and we're convinced we can afford the normal expense and we've talked with the Sierra Club and it is going to reduce the ... CO2 in the United States," And then someone says, "Yeah, but, you know, there's not one technology company out there we can even call up and that can 
deliver"... we want to change that. It's like... they'll say,... "Thank God! All we need to do is call (Solar3)".

Our analysis reveals that when ecological goals dominate a hybrid venture, the approach to incentivizing stakeholders was found to be exclusionary. This was a stark contrast to the hybridized, open approach followed by our final category.

\section{Blended Coupling of Ecological and Commercial Identities}

The final hybrid identity category that emerged from our analysis is comprised of founders who expressed blended identity coupling. These entrepreneurs explained their motivations as based on a blend of both the ecological and commercial identities; they expressed the complementary nature of this blend and our analysis brought to light that neither one nor the other was drawn upon as more salient. Indeed, this blended identity was highly motivational in creating new ventures. For example, William Greer explained how excited he gets about pursuing business opportunities but linked this to his strong environmental ethos from his upbringing:

I can't remember how many times my dad yelled at me for standing there with the fridge door open wasting electricity...And so it's no surprise to me that I'm now involved in a renewable energy or a green company, because... it's been drummed into me from when I was young. But what I'm trying to get to is that it's not something which I've just seen - business opportunity, make money, OK, we're now green. This is something which I've been doing since I was a kid. (William Greer)

Further illuminating the blended integration of identities, Juan Jacobs told us that

he started his business as much for ecological reasons as for profit-making:

I'd spent 10 years doing non-profit environmental work. So, I was a passionate believer in clean energy and, you know, wanted to leave the world a better place than when I found it ... partly I felt like I could do more in the for-profit world than the non-profit world... partly my second child was born and I had no way to retire or put her through school. So, you know, a bunch of reasons. 
Indeed, a recurring reason articulated by this group of founders related to conceptualizing their career as an environmental entrepreneur is as a blending two sides of their identity through their work:

I think a lot of...us business folk do find the thing that we love to do the most we're probably going to be the best at. ... so this company connects me to my core values. This is what matters to me in life. This is what I came here to do. (Rachel Russell).

Heck Munroe told us about a previous business he had founded but that he and his cofounders had been too "motivated by economics"; he reflected:

After two or three years of doing that, I found it hugely unsatisfying, even though I was making more money than I'd made any time in my career. I think basically we were pushing paper around, and we were not solving anything... I mean, it sounds almost idealistic, but I wanted to do something that made more of a difference and that was more personally fulfilling. (Heck Munroe)

Such statements signaled that the commercially orientated identity was seen as not opposed to, but blended with, ecologically oriented identities. Heck had lamented how previous entrepreneurial experience had not done enough to fulfill his ecological identity, so now was the time to launch a venture that could "make a difference" as well as generate income. We label this category Blended and summarize it as: commitment to environmental entrepreneurship as a means to enact the perceived synergy between a founder's ecological and commercial identities.

Co-created Goals -Incentivizing for Self-selection. Entrepreneurs with blended identities were compelled to pursue simultaneous commercial and ecological goals; to do otherwise would not allow them to successfully integrate their identity:

Our mission is to advance sustainability in the built environment, to our vision and commitment and expertise to create high-performance, exemplary buildings which reduce their impact on the environment, are healthier for occupants, embrace social responsibility, and contribute to economic sustainability... It isn't 
just about green buildings, you know. It's about people and it's about profit as well. (Rachel Russell)

With hybridity built into their venture goals, this group of environmental entrepreneurs intentionally sought to appeal to all stakeholders. Commercial and ecological stakeholders were neither prioritized over each other, nor differentially pursued. For example, William Greer's website states:

At [Thermal Solar] we are strongly committed to providing simple and effective solutions for families and businesses concerned about climate change and rising energy costs. Our team has an excellent reputation in the solar thermal industry and we pride ourselves in offering the best customer service available. We are very passionate about what we do, working hard to push the industry in a positive direction and ensuring that your experience with [Name] is a positive and enjoyable one (Thermal Solar, Website).

Statements such as above offer a wide gambit of incentives so that a variety of stakeholders can self-select into the process and even interpret the goals to their liking (Fischer \& Reuber, 2011; Sarasvathy \& Dew, 2005b). This realization led us to begin to find linkages between founder identity and the literature on effectual logic (Sarasvathy, 2001; Sarasvathy, 2008). Effectuation describes how entrepreneurs utilize their identity, resources, and stakeholder commitments to create, rather than discover, new firms, markets, and opportunities. A variety of studies in multiple industries have shown that expert entrepreneurs commonly utilize effectual logic (see Read, Dew, Sarasvathy, Song, \& Wiltbank, 2009; Read, Song, \& Smit, 2009). However, there has been little linkage between the effectuation and hybrid organization literature streams, despite scholars recognizing that, “...cognitive approaches in general, and effectuation theory in particular, also offer considerable promise for building a stronger theoretical basis for social entrepreneurship research" (Dacin et al., 2011: 1206). 
Two particular aspects of effectual logic that resonated with our findings: 1) means, and specifically "who I am" as the basis for initiating a venture, and 2) selfselected stakeholders. A critical distinction of the effectual approach is that rather than seeking to legitimize their business and thus secure commitments from specific stakeholders, effectual entrepreneurs seek to create avenues for stakeholder self-selection. In the effectual process, stakeholders put "skin in the game" (i.e. dedicate resources to the venture) because they see an opportunity for co-creating the venture with the entrepreneur; thus, they create their own incentive.

We found the literature on effectuation to align with the approach taken by entrepreneurs with a blended identity. When ventures embodied the widest array of goals, this created opportunities for stakeholders to see whatever it is they wanted to see in the firm. Founders with a blended identity created firms that allowed for self-selection by stakeholders because they integrated commercial, ecological, and even additional logics into the firm's goals. This was in contrast to commercial dominant entrepreneurs, who would include ecologically motivated stakeholders, but did not attempt to create a broadly appealing firm; rather they focused on commercial logics and motivations. Our analysis revealed that blended identity entrepreneurs, on the other hand, were often unaware of how they were appealing to stakeholders; because their firms were open to interpretation by multiple logics, stakeholders saw what they wanted to see, and thus selfselected into the firm.

For example, William Greer told us how he specifically tried to find executives by talking about how they could work together to bring quality products to market, and how they could be part of a team developing long term relationships with their clients. 
However, Roger Bruno, a key executive in the firm, described the incentives he had for joining the firm quite differently. In our interviews, he emphasized salient identities including: 1) community member (his home state), 2) environmentalist, 3) patriot, and 4) entrepreneur:

.... one of the reasons why I wanted to bring the solar collectors that I saw ... to (my home state) was because I said, Wow, you know, we need this. This is important. You know... We're polluting our land with all these fossil fuels.

I don't want to get too political here, but I definitely believe that energy security is important. And reducing a dependency on foreign oil is important, because I believe some national security issues we have are tied in with our addiction to oil. And it is very important for us to create alternative technologies... energy technologies in order for our nation to be more energy independent and secure.

And it just made logical sense to me that, you know, if this is something we need, there's not only an opportunity to help people; there's an opportunity to, you know, do something entrepreneurial as well. (Roger Bruno, Stakeholder of William Greer)

Bryan Monge described his employees as being attracted by his carbon consulting firm's strong strategy and business plan (i.e. commercial logic), but Ken Roundy, an Account Executive, described his motivation to join Monge's firm as providing solutions to simultaneous commercial and environmental problems. He told us:

I believe strongly that we have our innovative spirit - the ability to solve all of the energy problems and environmental problems in front of us with new technology. And I can see it as clear and plain as the back of my hand. What I love about this [position] is the opportunity to articulate that to people who are looking for solutions. (Ken Roundy, Stakeholder)

Our research revealed that founders, with a blended hybrid founder identity, pursuing hybrid goals, believe they know how to incentivize different stakeholders; but even when that belief was misplaced, stakeholders self-selected into the venture. A key aspect of this process is that the entrepreneur need not predict the incentives that will 
appeal to a given stakeholder. Rather, blended identity and the resultant hybrid goals provided a built-in flexibility for appealing to stakeholders. This finding suggests that the promise of hybrid organizing may lie not only in combining traditionally oppositional logics, but also in expanding the potential for stakeholder self-selection. Further, the relationship between identity, goals, and stakeholder self-selection portends promising linkages between literature streams on hybrid organizing, entrepreneurial identity, and effectuation. We further develop these insights and possibilities below.

\section{DISCUSSION}

Why do some individuals engage in environmental entrepreneurship, combining commercial and ecological goals within a new organization? Given the widely perceived tension between these logics, how do such individuals delineate goals and recruit stakeholders? In this study, we sought to address these interrelated questions through an inductive study of 25 environmental entrepreneurs. Our findings extend current understandings of environmental entrepreneurship by unearthing the role of identity coupling in terms of both formulating venture goals and determining approaches to incentivizing stakeholders. While each of our informants exhibited salient identities linked to both ecological and commercial logics, there were greater or lesser degrees of coupling between these identities. Our study suggests that the weighting and extent of identity coupling led entrepreneurs to either: 1) forge their venture goals based on their ecological dominant identity and exclude stakeholders who were not aligned, 2) establish venture goals based on their commercial identity and pragmatically, and perhaps serendipitously, remain inclusive to all stakeholders, or 3) when identities were tightly coupled, and thus blended, create hybrid venture goals that enable stakeholders to self- 
select based on their own incentives. By shining a light on the role of identity beyond initial motivation, we began to explicate the role of self-selection in terms of how entrepreneurship can contribute to solving environmental problems.

\section{Hybrid Organizing as Generative}

We add to the hybrid organizing literature by illustrating the role of identity in motivating environmental entrepreneurship as a specific type of hybrid organization. Based on our findings, we define environmental entrepreneurship as: the use of both commercial and ecological logics to address environmental degradation through the creation of financially profitable organizations, products, services, and markets. While extant literature has focused largely on the challenges and issues of combining competing logics within an organization, there has been little written about the generative aspects of such combinations (but see Simms \& Robinson, 2009; Wry \& York, 2015 ). Our findings suggest that such tensions can provide motivation for initiating hybrid ventures, as each founder we interviewed exhibited salient identities bound to both commercial and ecological logics. In addition, we found that the degree of coupling between these two types of identities influences both the establishment of venture goals and the approach founders take to incentivizing stakeholders. We posit that founder identity is not only able to help explain the degree of initial or enduring tension within hybrid organizations, but may also play an important role in resolving such tension. While it is well understood that entrepreneurs vary in their motivations, and that this may be influenced by identity (Fauchart \& Gruber, 2011; Murnieks et al., 2012), only recently have the theoretical implications of identities embedded in conflicting logics received attention (Wry \& York, 2015). 
Our findings suggest that when entrepreneurs hold salient commercial and ecological identities, but these are loosely coupled (i.e. with one remaining more salient), they may have greater difficulty understanding and collaborating with diverse stakeholders. This was especially the case when the ecological identity was the more salient. Conversely, when each identity is similarly salient and tightly coupled within the self, our findings suggest that entrepreneurs will more easily empathize with a wide variety of stakeholders and will more easily negotiate solutions to any challenges arising from tension in the logics they seek to combine. Because salient identities are largely embedded in social relationships (Stets \& Burke, 2000; Stets \& Burke, 2005), we suspect those with an ecological dominant identity were wary of appearing to "sell out" by including commercially oriented stakeholders. However, commercial dominant founders saw little risk to involving all stakeholders, as they viewed even ecologically oriented stakeholders as instrumental to achieving their commercial goals. Our findings also support recent assertions (Wry \& York, 2015) that founders with identities related to multiple logics may be better equipped to create hybrid organizations, due to their ties in multiple social realms. Future work on hybrid organizations could further scrutinize the nuances of founder identity and how identity impacts the path such ventures take from founding to maturity. An identity-based approach portends great promise for examining the emergence of hybrid ventures across the individual, organizational, and field levels.

While the social entrepreneurship literature has long recognized the need to understand the motivations for the entrepreneurial pursuit of non-economic goals, (e.g. Grimes et al., 2013; Mair \& Marti, 2006; Short et al., 2009) this paper specifies the role of identity in the motivation for, and creation of, such ventures. Dacin and colleagues 
(Dacin et al., 2011), have proposed that we should focus on the social consequences of entrepreneurship rather than focusing on social entrepreneurship as a distinct type of entrepreneurial action, or a separate field of research. Our findings provide empirical support for their proposition. By understanding how entrepreneurs can simultaneously produce economic profits and address social welfare problems, the field of entrepreneurship might be closer to achieving its promise: developing theory that encompasses both the economic and sociocultural implications of entrepreneurial action (Venkataraman, 1997). Our findings suggest that an identity-based approach could advance such theorizing, by examining the implications of hybrid founder identities.

Beyond the entrepreneurship literature our findings have implications for the broader study of organizations and the natural environment. Sustainability scholars have recently called for increased focus on the role of hybrid organizations in addressing environmental and social issues. For example, Hoffman and Haigh (2014) write that hybrid organizations “.....are operating at odds with beliefs embedded in strategic management and corporate sustainability literatures." Our findings suggest that understanding the identity and processes at the heart of hybrid organizing may offer an alternative path for understanding when, why, and how environmental market failures can be addressed. Hybrid organizations, and specifically environmental entrepreneurship, offer the possibility of focusing on creative, rather than destructive, tension between commercial and ecological logics (Ehrenfeld \& Hoffman, 2013; McDonough \& Braungart, 2013). Our hope is these findings offer entrepreneurship as an enticing path for future research by sustainability scholars.

\section{Extending Identity and Entrepreneurship Research}


We expand research on identity and entrepreneurship by explicating how commercial and social welfare-based identities interact to not only shape the goals entrepreneurs set for their venture, but also shape the entrepreneur's approach to recruiting stakeholders. This study expands the role of identity in the entrepreneurial process by focusing attention on the entrepreneur's identity not only as an inventor, founder, or developer (Cardon et al., 2009), but also as an environmentalist. While Fauchart and Gruber (2011) discovered that some entrepreneurs may have a "missionary" identity linked to “...the ambition to advance a particular cause (social, environmental, etc.)" (p.942), they explicitly differentiate such individuals from the "Darwinian" entrepreneur who will "pursue his self-interest (making money, creating personal wealth, a business that will be inherited by the next generation)" (942). Our findings suggest that, at least in the case of hybrid organizations, founders may align with both to greater or lesser extents.

Fauchart \& Gruber (2011) suggested that Darwinian and communitarian identities may co-exist as "hybrid founder identity" and they posited that hybrid identities might be more commonplace in the future. This study significantly builds on their insight by showing three ways in which environmental entrepreneurs (and by extension, other founders of hybrid organizations) may simultaneously couple together missionary and Darwinian identities within themselves. By elaborating three types of hybrid founder identities, we show how ecological and commercials logics can simultaneously be enacted and pursued by a range of individuals with relatively little tension or conflict.

These findings suggest that scholars at the intersection of entrepreneurship and identity should further probe the impacts of identity beyond initial motivation. For 
example, identity could have important implications for firms gaining and maintaining legitimacy and securing resources beyond initial stakeholders (Navis \& Glynn, 2011). Indeed, the processes implicated in early stage entrepreneurship could well mean that the entrepreneur's identity itself is altered as a consequence of the venturing process. Future research could take a process approach to explore the emergence and development of hybrid organizations to investigate if time and experience leads to tighter identity coupling. When founders remain open to various paths and stakeholders during venture creation, their identity likely evolves through the venturing process. For example, as discussed above, Carlos Cartegena (\#14) never viewed himself as a businessperson, but he came to embrace this identity through a hybrid firm because "there's a lot more private capital in the world than there is philanthropic money." This study raises the possibility that the literature on identity and entrepreneurship could ask not only "How does identity influence entrepreneurial action?" but also, "How is identity changed through entrepreneurship?"

\section{Effectuation: Linking Identity and Stakeholder Incentives}

Further, our findings suggest intriguing ties between the literature on entrepreneurial identity and effectuation (Sarasvathy, 2008). In a detailed conceptualization of the entrepreneurial stakeholder acquisition process, Sarasvathy \& Dew (2005b) posited a model of self-selection rather than targeted selection. When the environment is predictable, and goals are fairly well-specified in advance, particular stakeholders can be targeted with a view to fulfilling those goals. But in the face of Knightian uncertainty and Marchian goal ambiguity, entrepreneurs are forced to be effectual, meaning, who comes on board determines what gets done rather than what 
needs to be done determining whom to try to get on board. This begs the question of how entrepreneurs can "pitch" to potential stakeholders and why and how exactly people selfselect into new ventures. The literature stream on effectuation offers several answers to this question.

At least one strong answer has to do with the notion of identity - the "who I am" in the bird-in-hand principle. Sarasvathy \& Dew (2005a: 393-394) explain this as follows:

But reasoning from identity works even when there is no causal link between action and outcome, when a yawning chasm seems to stretch between choice and consequence, or when an entrepreneur feels passionately about a particular course of action while having no idea whether it will lead to desirable outcomes. $\ldots$ And more generally, using identity-based decision criteria frees entrepreneurs from having to order their preferences for specific consequences of their choice, and allows them to take decisive action even in the face of Knightian uncertainty (Knight, 1921 ; Langlois \& Cosgel, 1993 ). That is because the notion of identity stands in the same relationship to preferences as procedural rationality does to substantive rationality (Simon, 1978). For example, when faced with identical circumstances, a macho identity may lead one to revenge, whereas a Christian identity may seek to forgive (Cosgel \& Minkler, 2004). In other words, identity consists of preferences for particular processes or ways of living and deciding, rather than for any particular consequences that the preferred processes may lead to. Identity may be fictive or real, freely chosen or socio-culturally constructed, good or evil.

While the concept of self-selected stakeholders is well known in the effectuation literature, so far scholars have said little about how founder identity may impact stakeholder self-selection. The key to the connection between identity and stakeholders appears to lie in goal ambiguity. If entrepreneurs have a clear focus on economic outcomes or on environmental outcomes, they are less likely to offer enough flexibility for effectual self-selection that requires entrepreneurs to be open to their goals being reshaped by incoming stakeholders. This might explain why we found evidence of the 
effectual process only in the case of blended entrepreneurs. As an example, take the quote from Heck Munroe describing how his biodiesel venture moved to a multi-plant business model in response to self-selection from a purely financial stakeholder:

Well, we'd been talking with the guy who became our fourth partner. He'd been our sort of financial ear. He was good enough to help us out for free, just reviewing our business plan and sitting in on discussions every two or three months....

... Brought him on board of January 2007. Revamped the business plans. He... really formulated this notion of multiple plants so we could offer a bigger deal and we went out with him to California and pitched this to three or four different companies. (Heck Munroe, Founder)

It is important to note that our study was not designed to tease out relationships between identity and effectuation. However, it does offer evidence of strong ties between identity and goal clarity, the latter being a crucial variable of importance in effectuation. On the one hand, as Sarasvathy \& Dew (Sarasvathy \& Dew, 2005a) argued, a strong identity can substitute for goal clarity in entrepreneurial decision making under uncertainty. On the other hand, as our data show, a strong identity can also lead to focused, perhaps premature, goals thereby hindering the stakeholder self-selection process. We have thus touched upon an interesting set of competing hypotheses about strength of identity and the feasibility (or not) of the effectual process.

Furthermore, we believe this set of competing hypotheses is particularly salient in applications of entrepreneurship to the resolution of public goods problems (Olson, 1971) involving common pool resources (Ostrom, 1990) and cooperative solutions to social welfare issues (Axelrod \& Hamilton, 1981). Indeed, while our evidence is limited in this regard, we suggest that future research could solidify and build upon our nascent findings as detailed in Figure 1. 


\section{Limitations}

As with any study, we note several potential weaknesses with this one. First, one might question if there was bias, as our interviews were conducted mostly with individuals who were at the time in the process of running or founding a business. What of those who failed? We appreciate that failure is a key consideration in the entrepreneurial journey but as our research was not a process study, this outcome fell beyond the scope of our study. However, it is important to note, as illustrated in Table 1, that when we returned to review the participants' online presence for later triangulation, we discovered that seven of the businesses at start-up stage of during the initial interviews never advanced to fully-fledged businesses (labeled "defunct"). One venture at the growth stage was disbanded after our observation period (Solar2). Four further ventures had become different entities i.e. bought-out, merged or scaled down. This suggests that there was limited survivor bias in our sample, as the founders we interviewed went on to experience differing degrees of (eventual) success.

Second, we acknowledge that our sample of 25 environmental entrepreneurs is relatively small. However, we note that our intention, and the intention of most grounded theory studies, is not to capture a population, but rather to seek out cases that are aligned with the phenomenon of interest. As we were interested in why and how individuals chose to engage in environmental entrepreneurship, a relatively small sample is justifiable for the creation of our initial theorizing. Others may wonder why we did not include more stakeholders in our study. We concur with Überbacher (2014) that studies of new ventures would benefit from the inclusion of additional data from an entrepreneur's audiences. However, in this study, we refer to the stakeholder interviews 
as part of our triangulation approach rather than as integral to our theorizing. We are theorizing here about how entrepreneurs approach incentivizing stakeholders rather than building knowledge on the effectiveness (or not) of such incentivizing from a stakeholders perspective. We do envisage the opportunity for future research to focus more deeply on stakeholders to explore the implications of co-created incentivizing.

Third, and related, one may argue that the phenomenon we observe may not be exclusive to environmental entrepreneurs, and that all entrepreneurs likely have multiple identities, and thus, motivations. We actually would agree; we believe the insights derived in this paper are generalizable to the broader population of entrepreneurs. But, we also believe the differences in multiple identities within entrepreneurs, and their resultant impacts on the ventures they create, would be much more subtle and difficult to examine empirically. The reason our study focused on environmental entrepreneurship is because the distance between commercial and ecological goals and logics has been highlighted repeatedly in the broader literature on sustainability (Gladwin, Kennelly, \& Krause, 1995; Hoffman \& Jennings, 2012; Hoffman, 1999; Hoffman, 2001; Lee \& Lounsbury, 2015), hybrid organizing (Jay, 2013; York et al., 2015), and identity (Wry \& York, 2015). Thus, environmental entrepreneurship presents a compelling and "extreme" context (Eisenhardt \& Graebner, 2007) for furthering our understanding of how different, and potentially conflicting, identities influence the venturing process.

Finally, one may argue that recall bias tainted our interview data, and that the founders we spoke with sought to portray themselves to generate approval from the interviewer. This would be a serious weakness if this study purported to capture the actual founding process over time; however, this was never our intention. Rather, as we 
were interested first in motivation, then later in identity, and finally in the founder's approach to stakeholder recruitment, there was little choice but to directly ask the founder. Further, as shown in Appendix 1, we did not directly question the founders about their identity, but rather, our insights emerged inductively as the first and second author iteratively coded the data, moving between the extant literature on identity theory and our emergent categories. While it was not tenable to go back in time to track these ventures, our use of archival web page data allowed us to triangulate our primary interview data with another source of data. This allowed us to explore firstly how the founders spoke about their own motivation and identity via their online bios and blogs, and secondly, how these founders chose to portray their firm to stakeholders during the time period of the study. For our specific research questions, this process afforded us the opportunity to access the very constructs we were hoping to capture i.e. any bias the interviewees exhibited in attempting to present themselves in alignment with a commercial, ecological, or hybrid logic. That is, such bias would capture the identity to which the founders aspired, how this was embedded in the venture's goals, and therefore, how they put their identity and venture goals to work as they set about approaching their stakeholders.

Beyond the contributions to existing theory detailed above, there are several implications of this study for entrepreneurs who wish to address social welfare issues through commercial ventures. First, in contrast to the extant literature that focuses on detailing the challenges of hybridity, our study suggests that hybridity at the individual level may offer advantages. When entrepreneurs hold identities embedded in multiple logics, they may be able to appeal more easily to a variety of stakeholders. More 
critically, such entrepreneurs may be ideally placed to empower stakeholders to see what they want to in the venture, rather than be embroiled in a lengthy, negotiated process to become skillful in their legitimation efforts (O'Neil \& Ucbasaran, 2016). This implies that environmental and social entrepreneurs would be well served to develop, and to portray, a tightly coupled, blended identity. Further, our study suggests caution when initiating hybrid ventures to avoid over-weighting the social welfare aspect of the venture, as such action led the entrepreneurs in our study to miss opportunities for constructive stakeholder engagement with more diverse audiences.

While this study only hints at potential integration between entrepreneurship and resolving public goods problems such as climate change, our hope is that others will see the promise Olson offered when he wrote ".. the incorporation of the concept of entrepreneurship in the provision of collective good into the model developed in this book does not contradict its logic or invalidate its conclusions, but rather enriches the argument, and makes it a better tool for the study of organization leadership and change" (1971: 178). Our intention is that this study meets the spirit of Ostrom's quote at the beginning of the paper by suggesting that environmental entrepreneurship can help to foster a "world of possibility" and enable "mutually productive outcomes" (1997). With an enriched understanding of how entrepreneurs can help to address environmental problems, entrepreneurship scholars are well positioned to offer original insights into the achievement of environmental sustainability. 


\section{REFERENCES}

Aldrich, H. 1999. Organizations Evolving. NY: NY: Sage Publications.

Aldrich, H. E., \& Fiol, C. M. 1994. Fools rush in? The institutional context of industry creation. Academy of Management Review, 19(4): 645626 pages.

Alvesson, M., \& Kärreman, D. 2007. Constructing mystery: Empirical matters in theory development. Academy of Management Review, 32(4): 1265-1281.

Ansari, S., Gray, B., \& Wijen, F. 2011. Fiddling while the ice melts? How organizational scholars can take a more active role in the climate change debate. Strategic Organization, 9(1): 70-76.

Ansari, S., Wijen, F., \& Gray, B. 2013. Constructing a Climate Change Logic: An Institutional Perspective on the "Tragedy of the Commons". Organization Science, 24(4): 1014-1040.

Austin, J., Stevenson, H., \& Wei-Skillern, J. 2006. Social and commercial entrepreneurship: same, different, or both? Entrepreneurship Theory and Practice, 30(1): 1-22.

Axelrod, R., \& Hamilton, W. D. 1981. The evolution of cooperation. Science, 211(4489): 1390-1396.

Battilana, J., \& Dorado, S. 2010. Building sustainable hybrid organizations: The case of commercial microfinance organizations. Academy of Management Journal, 53(6): 1419-1440.

Battilana, J., \& Lee, M. 2014. Advancing Research on Hybrid Organizing- Insights from the Study of Social Enterprises. The Academy of Management Annals, 8(1): 397-441.

Battilana, J., Sengul, M., Pache, A. C., \& Model, J. 2015. Harnessing Productive Tensions in Hybrid Organizations: The Case of Work Integration Social Enterprises. Academy of Management Journal, In Press.

Battiliana, J., Lee, M., Walker, J., \& Dorsey, C. 2012. In search of the hybrid ideal. Stanford Social Innovation Review, 10(3): 50-55.

Besharov, M., \& Smith, W. 2014. Multiple logics in organizations: Explaiining their varied nature and implications. Academy of Management Review, 39(3): 364381.

Cardon, M. S., Wincent, J., Singh, J., \& Drnovsek, M. 2009. The Nature and Experience of Entrepreneurial Passion. Academy of Management Review, 34(3): 511-532.

Charmaz, K. 2006. Constructing grounded theory: A practical guide through qualitative analysis: Sage Publications Limited.

Dacin, M. T., Dacin, P. A., \& Tracey, P. 2011. Social entrepreneurship: A critique and future directions. Organization Science, 22(5): 1203-1213.

Dacin, P. A., Dacin, M. T., \& Matear, M. 2010. Social Entrepreneurship: Why We Don't Need a New Theory and How We Move Forward From Here. Academy of Management Perspectives, 24(3): 37-57.

Dean, T., \& McMullen, J. S. 2007. Toward a theory of sustainable entrepreneurship: Reducing environmental degradation through entrepreneurial action. Journal of Business Venturing, 22(1): 50-76.

Ehrenfeld, J., \& Hoffman, A. 2013. Flourishing: A Frank Conversation about Sustainability. Palo Alto, CA: Stanford University Press. 
Eisenhardt, K., \& Graebner, M. 2007. Theory building from cases: Opportunities and challenges. Academy of Management Journal, 50(1): 25-32.

Energy Information Administration. 2007. Renewable Energy Annnual, 2005: US Department of Energy.

Fauchart, E., \& Gruber, M. 2011. Darwinians, communitarians, and missionaries: The role of founder identity in entrepreneurship Academy of Management Journal, 54(5): 935-957.

Fischer, E., \& Reuber, A. R. 2011. Social interaction via new social media:(How) can interactions on Twitter affect effectual thinking and behavior? Journal of business venturing, 26(1): 1-18.

Frederick, W. C. 1999. Values, Nature, and Culture in the American Corporation. Don Mills: Oxford University Press.

Gioia, D. A., Corley, K. G., \& Hamilton, A. L. 2013. Seeking Qualitative Rigor in Inductive Research Notes on the Gioia Methodology. Organizational Research Methods, 16(1): 15-31.

Gladwin, T. N., Kennelly, J. J., \& Krause, T.-S. 1995. Shifting Paradigms for Sustainable Development: Implications for Management Theory and Research. Academy of Management Review, 20(4): 874-907.

Glaser, B. G., \& Strauss, A. L. 1967. The discovery of grounded theory: Strategies for qualitative research: Aldine de Gruyter.

Goulding, C. 2002. Grounded theory: A practical guide for management, business and market researchers: SAGE Publications Limited.

Grimes, M. G., McMullen, J. S., Vogus, T. J., \& Miller, T. L. 2013. Studying the origins of social entrepreneurship: Compassion and the role of embedded agency. Academy of Management Review, 38(3): 460-463.

Haigh, N., \& Hoffman, A. J. 2012. Hybrid organizations. Organizational Dynamics, 41(2): 126.

Haigh, N., \& Hoffman, A. J. 2014. The New Heretics Hybrid Organizations and the Challenges They Present to Corporate Sustainability. Organization \& Environment, 27(3): 223-241.

Hall, J. K., Daneke, G. A., \& Lenox, M. J. 2010. Sustainable development and entrepreneurship: Past contributions and future directions. Journal of Business Venturing, 25(5): 439-448.

Hiatt, S., Sine, W., \& Tolbert, P. S. 2009. From Pabst to Pepsi: The Deinstitutionalization of Social Practices and the Creation of Entrepreneurial Opportunities.

Administrative Science Quarterly, 54(4): 635-667.

Hiatt, S. R., Grandy, J. B., \& Lee, B. H. 2015. Organizational Responses to Public and Private Politics: An Analysis of Climate Change Activists and U.S. Oil and Gas Firms. Organization Science, 26(6): 1769-1786.

Hoang, H., \& Gimeno, J. 2010. Becoming a founder: How founder role identity affects entrepreneurial transitions and persistence in founding. Journal of Business Venturing, 25(1): 41-53.

Hockerts, K. 2015. How Hybrid Organizations Turn Antagonistic Assets into Complementarities. California Management Review, 57(3): 83-106.

Hoffman, A., \& Jennings, P. D. 2012. The Social and Psychological Foundations of Climate Solutions. Journal: Solutions, 3: 58-65. 
Hoffman, A. J. 1999. Institutional evolution and change: Environmentalism and the US chemical industry. Academy of Management Journal, 42(4): 351-371.

Hoffman, A. J. 2001. From heresy to dogma: An institutional history of corporate environmentalism: Stanford Business Books.

Howard-Grenville, J., Buckle, S. J., Hoskins, B. J., \& George, G. 2014. Climate change and management. Academy of Management Journal, 57(3): 615-623.

IPCC. 2011. The IPCC Special Report on Renewable Energy Sources and Climate Change Mitigation: United Nations Environment Programme.

IPCC. 2013. Summary for Policymakers. In: Climate Change 2013: The Physical Science Basis. In T. F. Stocker, \& D. Qin (Eds.). Switzerland: IPCC.

IPCC. 2014. Climate Change 2014: Impacts, Adaptation and Vulnerability. In W. G. II (Ed.), Fifth Assesment Report (AR5). Geneva, Switzerland: Intergovernmental Panel on Climate Change.

Jay, J. 2013. Navigating paradox as a mechanism of change and innovation in hybrid organizations. Academy of Management Journal, 56(1): 137-159.

Kuckertz, A., \& Wagner, M. 2010. The influence of sustainability orientation on entrepreneurial intentions -- Investigating the role of business experience. Journal of Business Venturing, 25(5): 524-539.

Kvale, S. 1983. The qualitative research interview: A phenomenological and a hermeneutical mode of understanding. Journal of phenomenological psychology.

Lee, M.-D. P., \& Lounsbury, M. 2015. Filtering Institutional Logics: Community Logic Variation and Differential Responses to the Institutional Complexity of Toxic Waste. Organization Science, 26(3): 847-866.

Lenox, M., \& York, J. G. 2012. Environmental Entrepreneurship. In P. Bansal, \& A. J. Hoffman (Eds.), The Oxford Handbook of Business and the Natural Environment. New York: Oxford University Press.

Locke, K. 2001. Grounded theory in management research. London; Thousand Oaks, Calif.: Sage Publications.

Lounsbury, M., \& Glynn, M. A. 2001. Cultural entrepreneurship: Stories, legitimacy, and the acquisition of resources. Strategic Management Journal, 22(6-7): 545-564.

Mair, J., \& Marti, I. 2006. Social entrepreneurship research: A source of explanation, prediction, and delight. Journal of World Business, 41(1): 36-44.

Mair, J., \& Martí, I. 2006. Social entrepreneurship research: A source of explanation, prediction, and delight. Journal of World Business, 41(1): 36-44.

Mars, M. M., \& Lounsbury, M. 2009. Raging against or with the private marketplace? Logic hybridity and eco-entrepreneurship. Journal of Management Inquiry, 18(1): 4-13.

McDonough, W., \& Braungart, M. 2013. The Upcycle: Beyond Sustainability-Designing for Abundance: North Point Press.

Mead, G. H. 1934. Mind, Self \& Society from the Standpoint of a Behaviorist.

Chicago, IL.: Chicago Press.

Miller, T., Grimes, M., McMullen, J., \& Vogus, T. 2012. Venturing for others with heart and head: How compassion encourages social entrepreneurship. Academy of Management Review, 38(3): 460-463.

Muñoz, P., \& Dimov, D. 2015. The call of the whole in understanding the development of sustainable ventures. Journal of Business Venturing, 30(4): 632-654. 
Murnieks, C., \& Mosakowski, E. 2006. Entrepreneurial passion: An identity perspective, Paper presented at the annual meeting of the Academy of Management, Atlanta.

Murnieks, C. Y., Mosakowski, E., \& Cardon, M. S. 2012. Pathways of passion: identity centrality, passion, and behavior among entrepreneurs. Journal of Management.

Navis, C., \& Glynn, M. A. 2011. Legitimate distinctiveness and the entrepreneurial identity: Influence on investor judgments of new venture plausibility. Academy of Management Review, 36(3): 479-499.

O'Neil, I., \& Ucbasaran, D. 2016. Balancing "what matters to me" with "what matters to them": Exploring the legitimation process of environmental entrepreneurs. Journal of Business Venturing, 31(2): 133-152.

Olson, M. 1971. The logic of collective action: public goods and the theory of groups. Cambridge: Harvard University Press.

Ostrom, E. 1990. Governing the Commons: The Evolution of Institutions for Collective Action: Cambridge University Press.

Ostrom, E. 2010. Polycentric systems for coping with collective action and global environmental change. Global Environmental Change, 20(4): 550-557.

Ostrom, E. 2012. Nested externalities and polycentric institutions: must we wait for global solutions to climate change before taking actions at other scales? Economic Theory, 49(2): 353-369.

Pache, A.-C., \& Santos, F. 2013. Inside the hybrid organization: Selective coupling as a response to competing institutional logics. Academy of Management Journal, 56(4): 972-1001.

Pache, A. C., \& Santos, F. 2010. When worlds collide: The internal dynamics of organizational responses to conflicting institutional demands. The Academy of Management Review (AMR), 35(3): 455-476.

Pacheco, D. F., \& Dean, T. J. 2015. Firm responses to social movement pressures: A competitive dynamics perspective. Strategic Management Journal, 36(7): 1093 1104.

Pacheco, D. F., Dean, T. J., \& Payne, D. S. 2010. Escaping the green prison: Entrepreneurship and the creation of opportunities for sustainable development. Journal of Business Venturing, 25(5): 464-480.

Pacheco, D. F., York, J. G., \& Hargrave, T. J. 2014. The Coevolution of Industries, Social Movements, and Institutions: Wind Power in the United States. Organization Science, 25(6): 1609-1632.

Patzelt, H., \& Shepherd, D. A. 2011. Recognizing opportunities for sustainable development. Entrepreneurship Theory and Practice, 35(4): 631-652.

Pettigrew, A. M. 1990. Longitudinal field research on change: theory and practice. Organization Science, 1(3): 267-292.

Powell, E. E., \& Baker, T. 2014. It's What You Make of It: Founder Identity and Enacting Strategic Responses to Adversity. Academy of Management Journal, 57(5): 1406-1433.

Read, S., Dew, N., Sarasvathy, S. D., Song, M., \& Wiltbank, R. 2009. Marketing Under Uncertainty: The Logic of an Effectual Approach. Journal of Marketing, 73(3): $1-18$. 
Read, S., Song, M., \& Smit, W. 2009. A meta-analytic review of effectuation and venture performance. Journal of Business Venturing, 24(6): 573-587.

Russo, M. 2010. Companies on a mission: Entrepreneurial strategies for growing sustainably, responsibly, and profitably: Stanford University Press.

Russo, M. V. 2001. Institutions, Exchange Relations, and the Emergence of New Fields: Regulatory Policies and Independent Power Production in America, 1978-1992. Administrative Science Quarterly, 46(1): 57-86.

Russo, M. V. 2003. The emergence of sustainable industries: building on natural capital. Strategic Management Journal, 24(4): 317-331.

Sarasvathy, S., D. 2001. Causation and effectuation: Toward a theoretical shift from economic inevitability to entrepreneurial contingency. Academy of Management Review, 26(2): 243-263.

Sarasvathy, S. D. 2008. Effectuation : elements of entrepreneurial expertise. Cheltenham, UK; Northampton, MA: Edward Elgar.

Sarasvathy, S. D., \& Dew, N. 2005a. Entrepreneurial logics for a technology of foolishness. Scandinavian Journal of Management, 21(4): 385-406.

Sarasvathy, S. D., \& Dew, N. 2005b. New market creation through transformation. Journal of Evolutionary Economics, 15(5): 533-565.

Schaltegger, S., \& Wagner, M. 2011. Sustainable entrepreneurship and sustainability innovation: categories and interactions. Business Strategy and the Environment, 20(4): 222-237.

Schlange, L. E. 2006. What drives sustainable entrepreneurs, Applied Business and Entrepreneurship Association International Conference: 16-20. Kona, HI.

Schlange, L. E. 2009. Stakeholder Identification in Sustainability Entrepreneurship. Greener Management International(55): 13-32.

Shepherd, D. A., \& Patzelt, H. 2011. The New Field of Sustainable Entrepreneurship: Studying Entrepreneurial Action Linking "What Is to Be Sustained" With "What Is to Be Developed". Entrepreneurship Theory and Practice, 35(1): 137-163.

Shepherd, D. A., Patzelt, H., \& Baron, R. A. 2013. "I Care about Nature, but...": Disengaging Values in Assessing Opportunities that Cause Harm. Academy of Management Journal, 56(5): 1251-1273.

Short, J. C., Moss, T., W., \& Lumpkin, G. T. 2009. Research in social entrepreneurship: past contributions and future opportunities. Strategic Entrepreneurship Journal, 3(2): 161-194.

Simms, S. V., \& Robinson, J. 2009. Activist or entrepreneur? An identity-based model of social entrepreneurship. In J. Robinson, J. Mair, \& K. Hockerts (Eds.), International Perspectives on Social Entrepreneurship: 9-26. London, UK: Palgrave Macmillan.

Smith, W. K., Gonin, M., \& Besharov, M. L. 2013. Manging Social-Business Tensions: A Review and Research Agenda for Social Enterprise. Business Ethics Quarterly, 23(3): 407-442.

Stets, J. E., \& Burke, P. J. 2000. Identity theory and social identity theory. Social Psychology Quarterly: 224-237.

Stets, J. E., \& Burke, P. J. 2005. New Directions in Identity Control Theory. In S. R. Thye, \& E. J. Lawler (Eds.), Social Identification in Groups (Advances in Group Processes), Vol. 22: 43-64. Bingley, UK: Emerald Group Publishing. 
Strauss, A., \& Corbin, J. 1994. Grounded theory methodology. Handbook of qualitative research: $273-285$.

Stryker, S. 1980. Symbolic Interactionism: A Social Structural Version. Menlo Park, CA: Benjamin-Cummings Publishing Company.

Stryker, S., \& Burke, P. J. 2000. The Past, Present, and Future of an Identity Theory. Social Psychology Quarterly, 63(4): 284-297.

Suchman, M. C. 1995. Managing Legitimacy: Strategic and Institutional Approaches. Academy of Management Review, 20(3): 571-610.

Überbacher, F. 2014. Legitimation of new ventures: A review and research programme. Journal of Management Studies, 51(4): 667-698.

United States International Trade Commission. 2005. Renewable Energy Services: An Examination of U.S. and Foriegn Markets: United States International Trade Commission.

Van Maanen, J., Sørensen, J. B., \& Mitchell, T. R. 2007. THE INTERPLAY BETWEEN THEORY AND METHOD. Academy of Management Review, 32(4): 11451154.

Venkataraman, S. 1997. The distinctive domain of entrepreneurship research. In J. Katz, \& R. Brockhaus (Eds.), Advances in Entrepreneurship, Firm Emergence, and Growth, Vol. 3: 119-138. Greenwich, CT: JAI Press.

Venkataraman, S. 2002. Stakeholder Value Equilibration and the Entrepreneurial Process The Ruffin Series of the Society for Business Ethics, 3: 45-57.

Waldron, T. L., Fisher, G., \& Pfarrer, M. 2016. How Social Entrepreneurs Facilitate the Adoption of New Industry Practices. Journal of Management Studies, DOI: 10.1111/joms.12187.

Wry, T., \& York, J. 2015. An Identity Based Approach to Social Enterprise. Academy of Management Review, In Press.

York, J., Hargrave, T., \& Pacheco, D. 2015. Converging Winds: Logic Hybridization in the Colorado Wind Energy Field. Academy of Management Journal, In Press. doi: 10.5465/amj.2013.0657.

York, J. G., \& Venkataraman, S. 2010. The entrepreneur-environment nexus: Uncertainty, innovation, and allocation. Journal of Business Venturing, 25: 449463. 
TABLE 1

Founder/Firm Characteristics and Data Sources

\begin{tabular}{|c|c|c|c|c|c|c|c|c|}
\hline Firm & $\begin{array}{l}\text { Firm } \\
\text { Type/Name }\end{array}$ & Principal Activities & $\begin{array}{l}\text { Founder } \\
\text { Name }\end{array}$ & $\begin{array}{l}\text { Firm Status/ } \\
\text { Founding Year }\end{array}$ & $\begin{array}{l}\text { Firm Status (at } \\
\text { Second Data } \\
\text { Collection) }\end{array}$ & $\begin{array}{l}\text { No. of } \\
\text { Interviews }\end{array}$ & $\begin{array}{l}\text { Additional Data } \\
\text { Sources }\end{array}$ & $\begin{array}{l}\text { Founder } \\
\text { Identity Type }\end{array}$ \\
\hline 1 & Wind Energy & $\begin{array}{l}\text { Developed technology for wind } \\
\text { energy turbines }\end{array}$ & Rueben Blake & $\begin{array}{l}\text { Defunct } \\
2005\end{array}$ & Defunct & 3 & & $\begin{array}{l}\text { Commercial- } \\
\text { Dominant }\end{array}$ \\
\hline 2 & Biomass1 & $\begin{array}{l}\text { Developing technology for rural } \\
\text { energy production and distribution in } \\
\text { emerging economies }\end{array}$ & Colin Stroud & $\begin{array}{l}\text { Startup } \\
2008\end{array}$ & Survived & 2 & $\begin{array}{l}\text { Website, Website } \\
\text { Archive }\end{array}$ & $\begin{array}{l}\text { Commercial- } \\
\text { Dominant }\end{array}$ \\
\hline 3 & Biomass2 & $\begin{array}{l}\text { Creates and implements co- } \\
\text { generation plants for industry }\end{array}$ & Jeff Fielding & $\begin{array}{l}\text { Growth } \\
2004\end{array}$ & Survived & 1 & $\begin{array}{l}\text { Website, Website } \\
\text { Archive }\end{array}$ & $\begin{array}{l}\text { Commercial- } \\
\text { Dominant }\end{array}$ \\
\hline 4 & Biodiesel1 & Refines and markets biodiesel & Heck Munroe & $\begin{array}{l}\text { Startup } \\
2006\end{array}$ & Defunct & 1 & $\begin{array}{l}\text { Website, Website } \\
\text { Archive }\end{array}$ & Blended \\
\hline 5 & Thermal Solar & $\begin{array}{l}\text { Manufacturers thermal solar water } \\
\text { heating systems }\end{array}$ & $\begin{array}{l}\text { William } \\
\text { Greer }\end{array}$ & $\begin{array}{l}\text { Growth } \\
2003\end{array}$ & Survived & 2 & $\begin{array}{l}\text { Stakeholder } \\
\text { Interview, Website, } \\
\text { Website Archive } \\
\end{array}$ & Blended \\
\hline 6 & $\begin{array}{l}\text { Carbon } \\
\text { Consulting }\end{array}$ & $\begin{array}{l}\text { Markets renewable energy credits, } \\
\text { consulting and direct purchase of } \\
\text { renewable energy }\end{array}$ & Bryan Monge & $\begin{array}{l}\text { Growth } \\
2001\end{array}$ & Survived & 2 & $\begin{array}{l}\text { Stakeholder } \\
\text { Interview, Website } \\
\text { Website Archive } \\
\end{array}$ & Blended \\
\hline 7 & $\begin{array}{l}\text { Magnetic } \\
\text { Turbines }\end{array}$ & $\begin{array}{l}\text { Developed patented technology for } \\
\text { magnetic turbine }\end{array}$ & Fred Bussey & $\begin{array}{l}\text { Startup } \\
2004\end{array}$ & Survived & 2 & $\begin{array}{l}\text { Stakeholder } \\
\text { interview, Website, } \\
\text { Website Archive } \\
\end{array}$ & Blended \\
\hline 8 & $\begin{array}{l}\text { Small-Scale } \\
\text { Wind }\end{array}$ & Develop home-based wind energy & Leopold King & $\begin{array}{l}\text { Pre-Venture } \\
\text { NA }\end{array}$ & Defunct & 1 & & $\begin{array}{l}\text { Commercial- } \\
\text { Dominant } \\
\end{array}$ \\
\hline 9 & Biomass3 & $\begin{array}{l}\text { Develops and constructs biogas } \\
\text { energy production units }\end{array}$ & Joseph Albert & $\begin{array}{l}\text { Growth } \\
2001\end{array}$ & Survived & 1 & $\begin{array}{l}\text { Website, Website } \\
\text { Archive }\end{array}$ & $\begin{array}{l}\text { Ecological- } \\
\text { Dominant }\end{array}$ \\
\hline 10 & Geothermal & $\begin{array}{l}\text { Project management and engineering } \\
\text { consultation }\end{array}$ & Calvin Mayer & $\begin{array}{l}\text { Spin-off from } \\
\text { Mature } \\
2008 \\
\end{array}$ & Survived & 1 & $\begin{array}{l}\text { Website, Website } \\
\text { Archive }\end{array}$ & $\begin{array}{l}\text { Commercial- } \\
\text { Dominant }\end{array}$ \\
\hline 11 & Thermal Solar & $\begin{array}{l}\text { Manufactures thermal solar water } \\
\text { heating systems }\end{array}$ & David Bonnet & $\begin{array}{l}\text { Growth } \\
1997\end{array}$ & Survived & 2 & $\begin{array}{l}\text { Website, Website } \\
\text { Archive }\end{array}$ & $\begin{array}{l}\text { Commercial- } \\
\text { Dominant }\end{array}$ \\
\hline 12 & $\begin{array}{l}\text { Renewable } \\
\text { Energy } \\
\text { Investing }\end{array}$ & $\begin{array}{l}\text { Makes early stage investments in } \\
\text { renewable energy firms }\end{array}$ & $\begin{array}{l}\text { Aaron } \\
\text { Rawson }\end{array}$ & $\begin{array}{l}\text { Mature } \\
1997\end{array}$ & $\begin{array}{l}\text { Split into a } \\
\text { Foundation and } \\
\text { Investment Fund }\end{array}$ & 3 & $\begin{array}{l}\text { Stakeholder } \\
\text { Interviews (2), } \\
\text { Website, Website } \\
\text { Archive }\end{array}$ & $\begin{array}{l}\text { Ecological- } \\
\text { Dominant }\end{array}$ \\
\hline 13 & $\begin{array}{l}\text { Marine } \\
\text { Energy1 } \\
\end{array}$ & $\begin{array}{l}\text { Develops large-scale marine } \\
\text { installations }\end{array}$ & Noel Upton & $\begin{array}{l}\text { Growth } \\
1998 \\
\end{array}$ & Survived & 1 & $\begin{array}{l}\text { Website, Website } \\
\text { Archive }\end{array}$ & $\begin{array}{l}\text { Ecological- } \\
\text { Dominant } \\
\end{array}$ \\
\hline
\end{tabular}


TABLE 1

Founder/Firm Characteristics and Data Sources (Cont.)

\begin{tabular}{|c|c|c|c|c|c|c|c|c|}
\hline Firm & Firm Name & Principal Activities & $\begin{array}{l}\text { Founder } \\
\text { Name }\end{array}$ & $\begin{array}{l}\text { Firm Status/ } \\
\text { Founding Year }\end{array}$ & $\begin{array}{l}\text { Firm Status (at } \\
\text { Second Data } \\
\text { Collection) }\end{array}$ & $\begin{array}{l}\text { No. of } \\
\text { Interviews }\end{array}$ & $\begin{array}{l}\text { Additional Data } \\
\text { Sources }\end{array}$ & $\begin{array}{l}\text { Founder } \\
\text { Identity } \\
\text { Type }\end{array}$ \\
\hline 14 & Solar1 & Installs home photovoltaic systems & $\begin{array}{l}\text { Carlos } \\
\text { Cartagena }\end{array}$ & $\begin{array}{l}\text { Growth } \\
2004\end{array}$ & Survived & 1 & $\begin{array}{l}\text { Website, Website } \\
\text { Archive }\end{array}$ & $\begin{array}{l}\text { Ecological- } \\
\text { Dominant }\end{array}$ \\
\hline 15 & Solar2 & $\begin{array}{l}\text { Builds utility-sized concentrated solar power } \\
\text { systems }\end{array}$ & $\begin{array}{l}\text { Phillip } \\
\text { Waddell }\end{array}$ & $\begin{array}{l}\text { Growth } \\
2002\end{array}$ & Defunct & 1 & $\begin{array}{l}\text { Website, Website } \\
\text { Archive, Blogs, } \\
\text { Press Coverage }\end{array}$ & Blended \\
\hline 16 & $\begin{array}{l}\text { Marine } \\
\text { Energy2 }\end{array}$ & Builds small-scale marine energy generators & Lorenzo Cruz & $\begin{array}{l}\text { Startup } \\
2007\end{array}$ & Survived & 1 & $\begin{array}{l}\text { Website, Website } \\
\text { Archive }\end{array}$ & $\begin{array}{l}\text { Commercial } \\
\text {-Dominant }\end{array}$ \\
\hline 17 & Biodiesel2 & Biodiesel production & Timothy Pratt & $\begin{array}{l}\text { Startup } \\
2005\end{array}$ & Defunct & 2 & & $\begin{array}{l}\text { Commercial } \\
\text {-Dominant }\end{array}$ \\
\hline 18 & Solar3 & Develops new solar technology & $\begin{array}{l}\text { Raymond } \\
\text { Graybill }\end{array}$ & $\begin{array}{l}\text { Growth } \\
2007\end{array}$ & Survived & 2 & $\begin{array}{l}\text { Stakeholder } \\
\text { Interview, Website, } \\
\text { Website Archive }\end{array}$ & $\begin{array}{l}\text { Ecological- } \\
\text { Dominant }\end{array}$ \\
\hline 19 & $\begin{array}{l}\text { Renewable } \\
\text { Fuels }\end{array}$ & Builds renewable fuel stations & $\begin{array}{l}\text { Mitchell } \\
\text { Jenkins }\end{array}$ & $\begin{array}{l}\text { Startup } \\
\text { NA }\end{array}$ & Defunct & 1 & & $\begin{array}{l}\text { Ecological- } \\
\text { Dominant }\end{array}$ \\
\hline 20 & $\begin{array}{l}\text { Green } \\
\text { Building1 }\end{array}$ & $\begin{array}{l}\text { Consults on energy efficiency of new } \\
\text { construction }\end{array}$ & $\begin{array}{l}\text { Richard } \\
\text { Delaney }\end{array}$ & $\begin{array}{l}\text { Startup } \\
2006\end{array}$ & Defunct & 1 & & Blended \\
\hline 21 & Solar4 & Constructs photovoltaic solar collectors & $\begin{array}{l}\text { Douglas } \\
\text { Burke }\end{array}$ & $\begin{array}{l}\text { Mature } \\
1999\end{array}$ & Bought out & 1 & $\begin{array}{l}\text { Stakeholder } \\
\text { Interview, Website, } \\
\text { Website Archive }\end{array}$ & Blended \\
\hline 22 & $\begin{array}{l}\text { Energy } \\
\text { Efficiency }\end{array}$ & $\begin{array}{l}\text { Constructs windows which enhance energy } \\
\text { efficiency }\end{array}$ & $\begin{array}{l}\text { Ben } \\
\text { Harrelson }\end{array}$ & $\begin{array}{l}\text { Growth } \\
1989\end{array}$ & Bought out & 1 & $\begin{array}{l}\text { Stakeholder } \\
\text { Interview, Website, } \\
\text { Website Archive }\end{array}$ & $\begin{array}{l}\text { Ecological- } \\
\text { Dominant }\end{array}$ \\
\hline 23 & $\begin{array}{l}\text { Wind \& } \\
\text { Solar } \\
\text { Energy }\end{array}$ & $\begin{array}{l}\text { Develops utility scale wind and solar energy } \\
\text { projects }\end{array}$ & Juan Jacobs & $\begin{array}{l}\text { Mature (Wind) } \\
\text { Startup (Solar) } \\
\text { 1999/2009 } \\
\end{array}$ & Survived & 2 & $\begin{array}{l}\text { Website, Website } \\
\text { Archive }\end{array}$ & Blended \\
\hline 24 & $\begin{array}{l}\text { Wind Farm } \\
\text { Siting }\end{array}$ & $\begin{array}{l}\text { Engages in wind testing and analysis for } \\
\text { wind farm development }\end{array}$ & $\begin{array}{l}\text { James } \\
\text { Bennett }\end{array}$ & $\begin{array}{l}\text { Startup } \\
2008\end{array}$ & Survived & 2 & $\begin{array}{l}\text { Website, Website } \\
\text { Archive }\end{array}$ & Blended \\
\hline 25 & $\begin{array}{l}\text { Green } \\
\text { Building2 }\end{array}$ & $\begin{array}{l}\text { Green building and energy efficiency } \\
\text { consultant }\end{array}$ & $\begin{array}{l}\text { Rachel } \\
\text { Russell }\end{array}$ & $\begin{array}{l}\text { Growth } \\
1980\end{array}$ & Survived & 1 & $\begin{array}{l}\text { Website, Website } \\
\text { Archive }\end{array}$ & Blended \\
\hline
\end{tabular}


TABLE 2

\section{Illustrative Examples of First Order Coding to Second Order Themes}

\begin{tabular}{|c|c|c|c|}
\hline Excerpts from Interview Scripts & $\begin{array}{l}\text { First Author's Initial } \\
\text { Code \& Description }\end{array}$ & $\begin{array}{c}\text { Second Author's Initial Code \& } \\
\text { Description }\end{array}$ & $\begin{array}{l}\text { Final First Order } \\
\text { Code }\end{array}$ \\
\hline \multicolumn{4}{|c|}{ Examples of First Order Coding leading to Commercial Dominant Identity } \\
\hline $\begin{array}{l}\text { It's quite rewarding to go from } \\
\text { about a four-man operation to a 180- } \\
\text { man operation now - keeping all } \\
\text { those people busy and making a } \\
\text { living. } \\
\text { (Calvin Mayer, Founder) }\end{array}$ & $\begin{array}{l}\text { "Economic Motivation" } \\
\text { Respondent discusses } \\
\text { profits, money, wealth, } \\
\text { etc. as a motivation for } \\
\text { starting or becoming } \\
\text { involved in the business. }\end{array}$ & $\begin{array}{l}\text { "Deriving enjoyment from profit- } \\
\text { making activities" } \\
\text { Statements about becoming an } \\
\text { entrepreneur due to enjoying } \\
\text { commercial side of business. }\end{array}$ & $\begin{array}{c}\text { Founder's interest } \\
\text { in profit-making } \\
\text { activity }\end{array}$ \\
\hline $\begin{array}{l}\text { I didn't mean to be but apparently } \\
\text { I'm a die-hard entrepreneur and just } \\
\text { the way it is. (David Bonnet, } \\
\text { Founder) }\end{array}$ & $\begin{array}{l}\text { "Economic Motivation" } \\
\text { Respondent discusses } \\
\text { profits, money, wealth, } \\
\text { etc. as a motivation for } \\
\text { starting or becoming } \\
\text { involved in the business. }\end{array}$ & $\begin{array}{l}\text { "Explicit business person } \\
\text { reference" } \\
\text { Statements that express strong } \\
\text { identification with being a profit- } \\
\text { making business person. }\end{array}$ & $\begin{array}{l}\text { Articulation of self } \\
\text { as a profit-seeking } \\
\text { business person }\end{array}$ \\
\hline \multicolumn{4}{|c|}{ Examples of First Order Coding leading to Blended Identity } \\
\hline $\begin{array}{l}\text { I think a lot of...us business folk do } \\
\text { find the thing that we love to do the } \\
\text { most we're probably going to be the } \\
\text { best at. ... so this company connects } \\
\text { me to my core values. This is what } \\
\text { matters to me in life. This is what I } \\
\text { came here to do. } \\
\text { (Rachel Russell, Founder) }\end{array}$ & $\begin{array}{l}\text { "Mixed Motivation" } \\
\text { Participant refers to } \\
\text { their values as } \\
\text { motivation for getting } \\
\text { involved in or starting } \\
\text { the business. }\end{array}$ & $\begin{array}{l}\text { "Values-Business Ethos Links" } \\
\text { Statements stressing the } \\
\text { importance of the entrepreneurs } \\
\text { business AND personal values. }\end{array}$ & $\begin{array}{c}\text { Comments on } \\
\text { suitability of } \\
\text { matching own } \\
\text { values with doing } \\
\text { business }\end{array}$ \\
\hline $\begin{array}{l}\text { If you get this right, this can be a } \\
\text { huge, high-potential thing. It's an } \\
\text { immense professional challenge. } \\
\text { And if you can get it done, it's really } \\
\text { worthwhile. And not just because of } \\
\text { the hard commercial challenge and } \\
\text { opportunity aspects, but also } \\
\text { because of the altruistic... the main } \\
\text { motivational issue...is, if we have } \\
\text { achieved one goal, we've taken this } \\
\text { technology to a major form in the } \\
\text { world, then that's mission success. } \\
\text { (Doug Burke, Founder) }\end{array}$ & $\begin{array}{l}\text { "Environmental } \\
\text { Entrepreneurship" } \\
\text { Participant describes } \\
\text { an economic and social } \\
\text { impacts approach. }\end{array}$ & $\begin{array}{l}\text { "Values-Business Ethos Links" } \\
\text { Statements stressing the } \\
\text { importance of the entrepreneurs } \\
\text { business AND personal values. }\end{array}$ & $\begin{array}{c}\text { Personal } \\
\text { commitment to } \\
\text { environmental } \\
\text { entrepreneurship } \\
\text { to achieve low cost, } \\
\text { high quality, clean } \\
\text { solutions for good } \\
\text { of planet, others, } \\
\text { and ultimately self. }\end{array}$ \\
\hline
\end{tabular}


TABLE 3

\section{Data Structure}

\begin{tabular}{|c|c|c|}
\hline First Order Codes & $\begin{array}{l}\text { Second Order } \\
\text { Themes }\end{array}$ & $\begin{array}{l}\text { Aggregate } \\
\text { Theoretical } \\
\text { Dimensions }\end{array}$ \\
\hline $\begin{array}{l}\text { - Articulation of self as a profit-seeking businessperson } \\
\text { - Statements reflecting founder's interest in profit-making } \\
\text { activity } \\
\text { - Talk of personal commitment to grow renewable energy for } \\
\text { increasing business opportunities }\end{array}$ & $\begin{array}{c}\text { Commercial } \\
\text { Dominant Identity }\end{array}$ & \multirow{3}{*}{$\begin{array}{l}\text { Hybrid } \\
\text { Founder } \\
\text { Identity } \\
\text { Coupling }\end{array}$} \\
\hline $\begin{array}{l}\text { - Comments on suitability of matching own (environmental) } \\
\text { values with doing business } \\
\text { - Articulations of the wider value of combining business and } \\
\text { environmentalism } \\
\text { - Personal commitment to environmental entrepreneurship to } \\
\text { achieve low cost, high quality, clean solutions for good of } \\
\text { planet, others, and ultimately self. }\end{array}$ & $\begin{array}{l}\text { Blended } \\
\text { Identity }\end{array}$ & \\
\hline $\begin{array}{l}\text { - Statements reflecting founder's environmental/ social welfare } \\
\text { beliefs } \\
\text { - Personal commitment to environmental entrepreneurship for } \\
\text { tackling climate change }\end{array}$ & $\begin{array}{c}\text { Ecological Dominant } \\
\text { Identity }\end{array}$ & \\
\hline $\begin{array}{l}\text { - Commercial emphasis e.g. make money and/or exit the } \\
\text { business } \\
\text { - Statements on profit opportunity as primary purpose of } \\
\text { launching venture }\end{array}$ & Commercial Goals & \multirow{3}{*}{ Venture Goal } \\
\hline $\begin{array}{l}\text { - Hopes to contribute to growing to improve upon incumbents' } \\
\text { environmental impact } \\
\text { - Statements on using venture as vehicle to 'leave a better world' }\end{array}$ & Ecological Goals & \\
\hline $\begin{array}{l}\text { - Comments showing that both sustainability and profit } \\
\text { outcomes are embedded in 'essence' of the venture } \\
\text { - Statements on the practice of addressing environmental issues } \\
\text { using business mechanisms (e.g. profit-making) }\end{array}$ & Hybrid Goals & \\
\hline $\begin{array}{l}\text { - Comments on profit/ personal wealth creation driving } \\
\text { stakeholders' venture involvement } \\
\text { - Effort to incentivize involvement based on financial value of } \\
\text { venture involvement }\end{array}$ & $\begin{array}{c}\text { Inclusive } \\
\text { Incentivizing }\end{array}$ & \multirow{3}{*}{$\begin{array}{l}\text { Stakeholder } \\
\text { Incentivizing }\end{array}$} \\
\hline $\begin{array}{l}\text { - Comments on environmental aspects (e.g. values/ passions) } \\
\text { driving stakeholders' venture involvement } \\
\text { - Effort to incentivize involvement based on social* value of } \\
\text { venture involvement } \\
\text { *'Social" includes environmental and community value }\end{array}$ & $\begin{array}{c}\text { Exclusive } \\
\text { Incentivizing }\end{array}$ & \\
\hline $\begin{array}{l}\text { - Articulation of efforts to offer multiple messages } \\
\text { - Evidence suggesting how stakeholders self-select incentives } \\
\text { for venture involvement }\end{array}$ & $\begin{array}{l}\text { Co-Created } \\
\text { Incentivizing }\end{array}$ & \\
\hline
\end{tabular}


TABLE 4

\section{Exemplary Quotes for Each Hybrid Founder Identity Type}

\begin{tabular}{|c|c|}
\hline $\begin{array}{l}\text { Commercial } \\
\text { Dominant } \\
\text { Identity }\end{array}$ & $\begin{array}{l}\text { - I didn't mean to be but apparently I'm a die-hard entrepreneur and just the way it is. You just have to keep slugging it out and dealing with the day to day. But } \\
\text { things are slowly getting better and we're going to definitely do over a million this year and hopefully way over and [there are] just a lot of challenges along the } \\
\text { way trying to pull things together in an under-funded scenario. (David Bonnet, Founder) } \\
\text { Once everybody's got enough engineering information about that project - that we know how much money it will make and how much it will cost and how long it } \\
\text { takes, and we've reduced the uncertainty a lot - we want to sell the company to somebody else, like a big wind project development company. My intention is to } \\
\text { get it going, flip it, and get out of it. (Lorenzo Cruz, Founder) } \\
\text { (The founder of current employer) made himself into a millionaire. He was not an educated man, but he had an idea and he worked hard to make it happen. And } \\
\text { now his five kids own the company. They don't do a damn thing and they're millionaires, and it just galls me. They fell in the money pit, and they don't do } \\
\text { anything. And I don't want to work for them anymore...I don't want to be working until I'm } 72 \text { and my daughter's } 22 \text { and just come out of college... You know, } \\
\text { I'm in need of funding. And I've got a dream. I know there's a market. (Leopold King, Founder) } \\
\text { It's quite rewarding to go from about a four-man operation to a 180-man operation now - keeping all those people busy and making a living. (Calvin Mayer, } \\
\text { Founder) } \\
\text { [the main motivation is] to turn a profit making biodiesel. I mean... I... it's hard to say... I guess there's a mission of producing alternative fuel in the local area that } \\
\text { I live. But I think that's a secondary. I mean, you obviously have to be able to make a living. (Timothy Pratt, Founder) }\end{array}$ \\
\hline $\begin{array}{l}\text { Bler } \\
\text { Ider }\end{array}$ & $\begin{array}{l}\text { - If you get this right, this can be a huge, high-potential thing. It's an immense professional challenge. And if you can get it done, it's really worthwhile. And not just } \\
\text { because of the hard commercial challenge and opportunity aspects, but also because of the altruistic... What I say to myself is that when I finally close the door and } \\
\text { retire, what will I judge success on? [will it be that] we've made a successful company that's very big and doing well, and I've made money, and the people around } \\
\text { me who've invested in it have made money, and all this sort of stuff? Not really. That's almost a condition for success. But it's not the main objective. The main } \\
\text { objective and how I would judge myself... the main motivational issue...is, if we have achieved one goal, we've taken this technology to a major form in the world, } \\
\text { then that's mission success. (Doug Burke, Founder) } \\
\text { - When we [co-founders] first met, our discussions...were a way of affirming that what we're doing is required, and that the way the economic system worked now } \\
\text { needed to be changed and entrepreneurs can play a role in that. And therefore, if things need to change and we have a tool at our disposal, we should use it. So I } \\
\text { think... the values and our discussions were very important at that time....and we were both... well, at least, you know, we were under pressure from significant } \\
\text { others who were saying... who were questioning the whole thing. (Rueben Blake, Founder) } \\
\text { The founder's and my personal motivation is that we want to do these things [in renewable energy], to do the right thing. That's a very strong motivation but we're } \\
\text { not blinded by that, to do that you have to have a product and a service and a company that is market-driven and that understands the economics. (Russ Wood, } \\
\text { Stakeholder of Raymond Graybill) }\end{array}$ \\
\hline $\begin{array}{l}\text { gical } \\
\text { inant } \\
\text { ity }\end{array}$ & $\begin{array}{l}\text { - .. I agree with [name] who wrote his new book saying "Capitalism is destroying the planet." Well, I thought that for } 30 \text { years. So don't call me a capitalist... } \\
\text { Capitalism is an exploitive system. It's } 120 \text { years old. Finance capitalism is the worst form of that system. Business has been around for } 3,000 \text { years. Business is } \\
\text { business, and people really have to understand the difference. Corporate finance, corporate capitalism, finance capitalism sucks. And it doesn't work, and it just } \\
\text { exploits. And basically, it's not sustainable...(Carlos Cartagena, Founder) } \\
\text { - I said, "Environment, I want to do something with the environment but it has to be profitable."... None of us have to worry about having bread and butter in the } \\
\text { morning, you know? And so then you really think about what can you do meaningful with your time... And so I said, well... if I could do something that is } \\
\text { meaningful, that would be something that I would really want to put my effort into (Aaron Rawson, Founder) } \\
\text { - If you want to know more about what my motivation is, it's not about money ... but this is what is in my heart - I'm thinking about that. It's a very dangerous road } \\
\text { we are going with this energy thing, with all these wars in the world, all this... I think it's all about oil...It's not just about the environment. It's also about keeping } \\
\text { a peaceful world. I think that is something which drives me nuts too. (Joseph Albert, Founder) } \\
\text { He wanted to do something that would have a greater impact on the coming environmental challenges that we're facing, particularly climate change. And [he] got } \\
\text { the idea that it would be a great economic opportunity to be able to invest in renewable energy companies. (Paul Gabriels, Stakeholder of Aaron Rawson) }\end{array}$ \\
\hline
\end{tabular}


TABLE 5

\section{Venture Goals and Stakeholder Incentivizing (Corresponding to Identity Type)}

\begin{tabular}{|c|c|c|}
\hline & Venture Goals & Stakeholder Incentivizing -Inclusive \\
\hline $\begin{array}{l}\text { Commercial } \\
\text { Dominant } \\
\text { Identity }\end{array}$ & $\begin{array}{l}\text { - } \text { [Brand name] is designed as a high-tech distributed energy } \\
\text { technology company with a global market. It's focused on large- } \\
\text { volume manufacturing and sales. We intend to make lots and lots } \\
\text { of small turbines and sell them all over the world... it's intended as } \\
\text { a high-growth venture capitalist type deal. And the VCs, they want } \\
\text { to sell out after five years and make a fortune. I don't know if I'll } \\
\text { sell out, but I want to make the fortune. (Lorenzo Cruz, Founder) } \\
\text { [I got into biodiesel by] just trying to cut costs... it's really about } \\
\text { pennies, dollars, and cents, and volume. And I had a friend who is } \\
\text { a musician, really into biodiesel and we'd talk about it every once } \\
\text { in a while and it kind of planted a seed in my head, and he finally } \\
\text { said, "You know, why don't you do this? Why don't you try it?" } \\
\text { So I tried it. And for a solid year and a half I fueled two dump } \\
\text { trucks and a tractor-trailer with biodiesel. Then I realized "why } \\
\text { burn the gold - and the [trucking] business was barely making } \\
\text { money- when you can sell Biodiesel?". So I first started selling it } \\
\text { when I was confident enough that it was saleable (Timothy Pratt, } \\
\text { Founder) } \\
\text { Our thinking as a group is that there is a market in the commercial } \\
\text { building space for small-scale wind turbine technology... So we're } \\
\text { looking at that as an opportunity and [that] is sort of coming } \\
\text { together, like the perfect storm of opportunity for us to try and } \\
\text { pursue this. (Leopold King, Founder) } \\
\text { Energy and renewable energy is absolutely the major opening } \\
\text { field. Predictions are it's going to far exceed even the computer } \\
\text { boom as far as the size of it. It's a trillion-dollar market, and } \\
\text { there's so many different things that you can do in it. You know, } \\
\text { so I just see that as kind of being the new frontier if you want to } \\
\text { get into something new that's not the same old beaten path (David } \\
\text { Bonnet, Founder) }\end{array}$ & 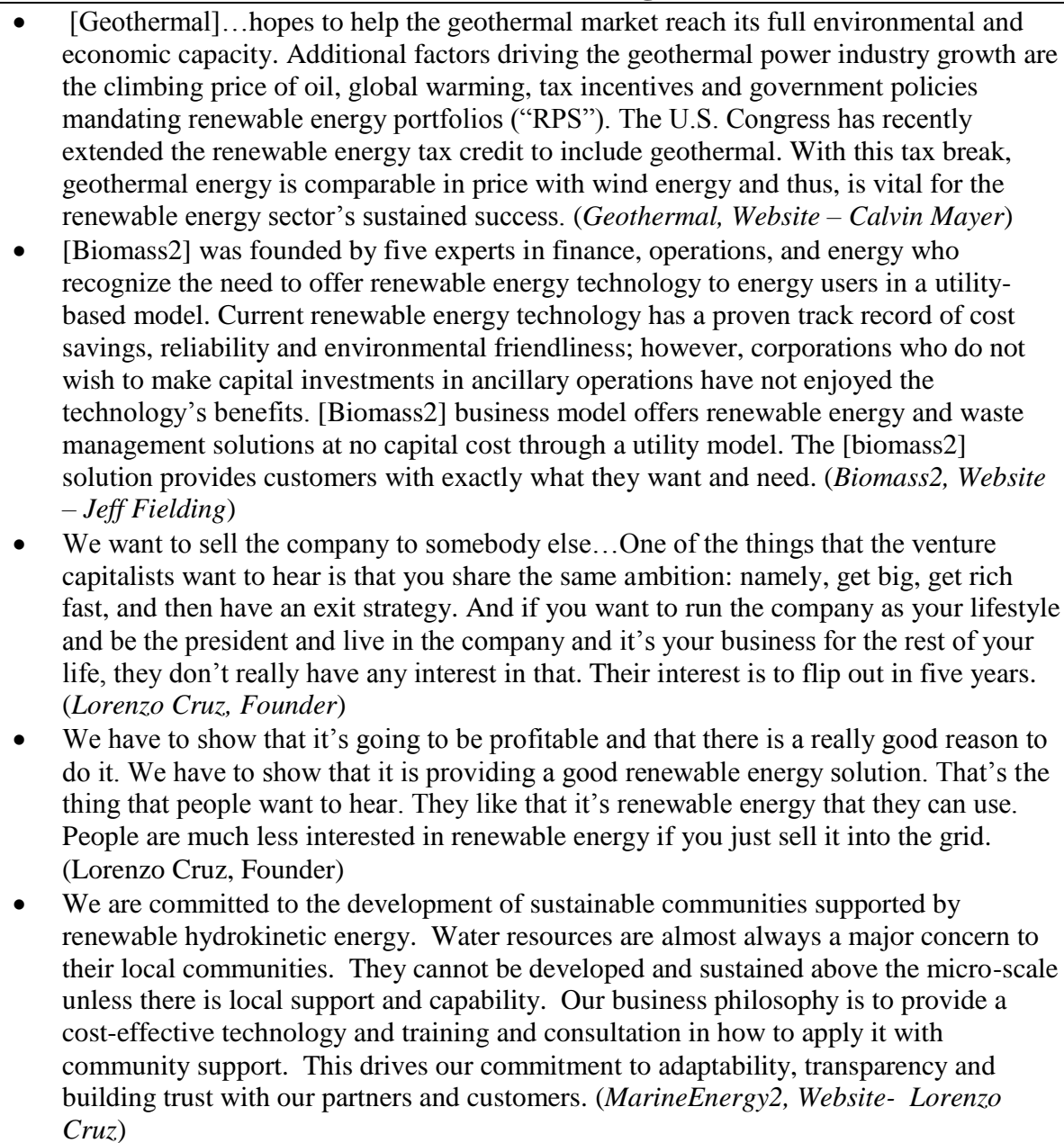 \\
\hline
\end{tabular}


TABLE 5

\section{Venture Goals and Stakeholder Incentivizing (Corresponding to Identity Type)}

\begin{tabular}{|c|c|c|}
\hline & Venture Goals & Stakeholder Incentivizing -Co-Creation \\
\hline $\begin{array}{l}\text { Blended } \\
\text { Identity }\end{array}$ & $\begin{array}{l}\text { - Our mission is to] re-energize the world and change the world and } \\
\text { try to get a positive out of a negative. If you look at what our real } \\
\text { mission is, we're almost trying to get extra gas mileage out of a } \\
\text { tank of gas. (Chris Johnson, Stakeholder of Fred Bussey) } \\
\text { - } \text { [Solar2's] mission is to invent, manufacture and sell the world's } \\
\text { most innovative and affordable solar collectors. Our company } \\
\text { strives to become part of the solution to global problems including } \\
\text { climate change, energy security and sustainability. (Solar2, } \\
\text { Website, Phillip Waddle) } \\
\text { - We wanted to design the business to be operated as sustainably as } \\
\text { we could, using waste products as a feedstock as much as we } \\
\text { could, and have our operations be as green as we could make them. } \\
\text { So we deliberately set out to design a sustainable renewable energy } \\
\text { business. (Heck Munroe, Founder) } \\
\text { Our mission is to advance sustainability in the built environment, } \\
\text { to our vision and commitment and expertise to create high- } \\
\text { performance, exemplary buildings which reduce their impact on } \\
\text { the environment, are healthier for occupants, embrace social } \\
\text { responsibility, and contribute to economic sustainability... It isn't } \\
\text { just about green buildings, you know. It's about people and it's } \\
\text { about profit as well. (Rachel Russell, Founder) } \\
\text { In a nutshell, we are developing photovoltaics as a sustainable, } \\
\text { environmentally benign technology - and exploiting the } \\
\text { commercial opportunities afforded by this rapidly growing market. } \\
\text { (Solar4, Website, Doug Burke) } \\
\text { We are a green energy company trying to make a difference in the } \\
\text { world. Our engineers and physicists are working on developing } \\
\text { new technologies to produce green energy and to decrease the use } \\
\text { of fossil fuel and carbon emissions. (Magnetic Turbines, Website - } \\
\text { Fred Bussey) } \\
\text { We hold true to our belief that every individual and every business } \\
\text { has a right to choose how the electricity they buy is produced. We } \\
\text { steadfastly believe in renewable energy as an affordable, } \\
\text { mainstream option that is only beginning to catch hold... Our } \\
\text { mission: To lead the migration to sustainable energy that is good } \\
\text { for the environment, the economy, and all current and future } \\
\text { generations (Carbon Consulting, Website - Brian Monge) }\end{array}$ & 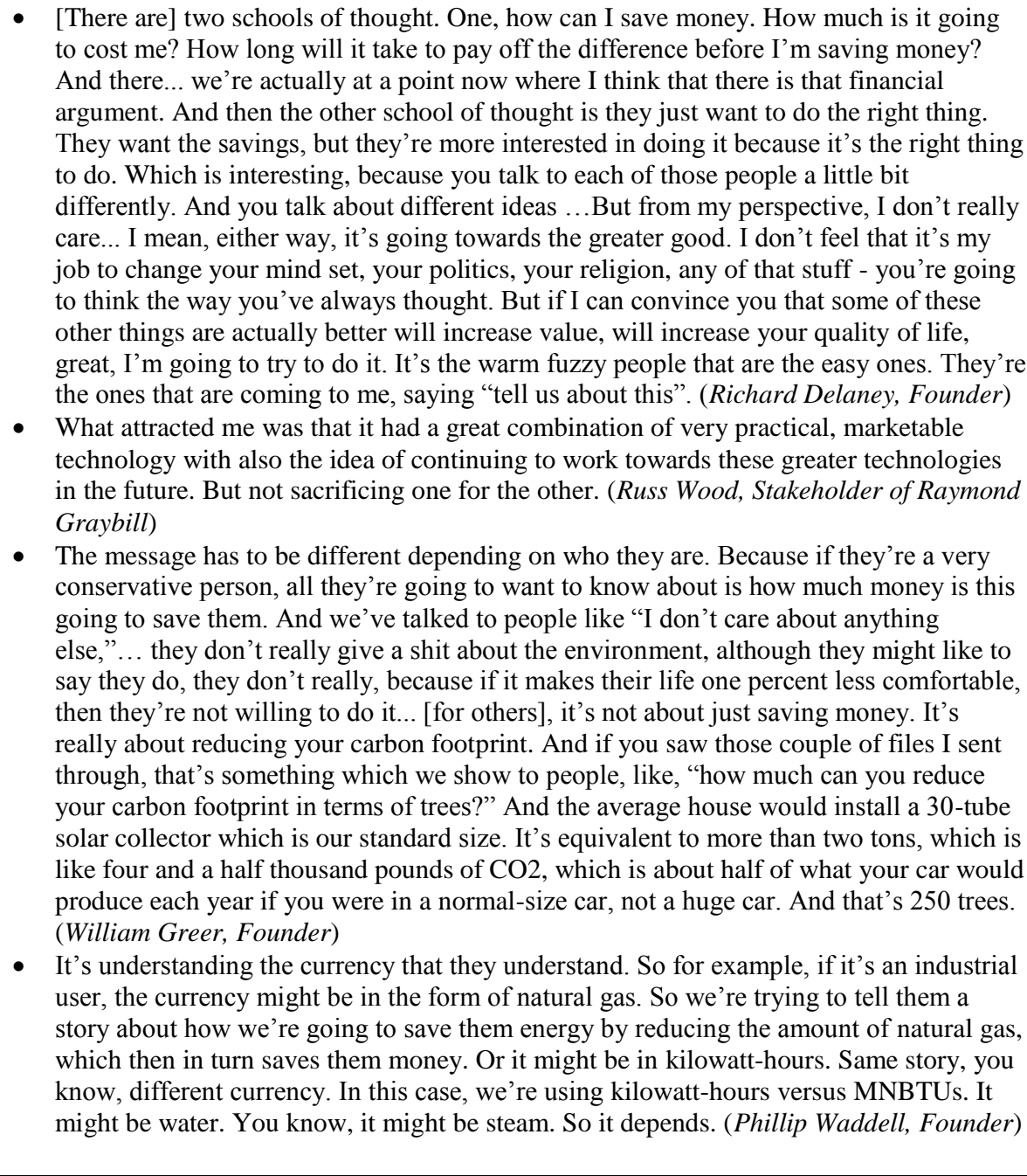 \\
\hline
\end{tabular}


TABLE 5

Venture Goals and Stakeholder Incentivizing (Corresponding to Identity Type)

\begin{tabular}{|c|c|c|}
\hline & Venture Goals & Stakeholder Incentivizing -Exclusionary \\
\hline $\begin{array}{l}\text { Ecological } \\
\text { Dominant } \\
\text { Identity }\end{array}$ & $\begin{array}{l}\text { The mission is to bring the world the benefits of electronically } \\
\text { tintable glass into the construction markets. And so why is that } \\
\text { important? Buildings are responsible for } 40 \% \text { of the energy } \\
\text { consumption in North America. There's approximately } 100 \text { quads } \\
\text { of energy used in total, and } 40 \text { of those quads go to buildings...The } \\
\text { carbon footprint that buildings result from consuming that much } \\
\text { energy is even larger... And I do believe that we're doing } \\
\text { something very meaningful and important...to make a very positive } \\
\text { impact on the carbon footprint of buildings. (Ben Harrelson, } \\
\text { Founder) } \\
\text { - I got a sense of what could be done with one guy and what a small } \\
\text { group of people can do. You know, you can go out and conquer the } \\
\text { world with a new business venture, especially in energy today. It's } \\
\text { got to be solved... But don't rely on the corporations to solve } \\
\text { it...(Carlos Cartagena, Founder) } \\
\text { - I think making a difference. Um, having a legacy may be a strong } \\
\text { word. I don't know. At the end of my career and the end of my life, } \\
\text { if I look back if I can call it leaving a legacy. But that would be my } \\
\text { goal... to leave people and the planet in a better condition than } \\
\text { when I arrived. I would say that's the goal and motivation. (Rachel } \\
\text { Russell, Founder) } \\
\text { - We assume stewardship responsibility for the earth's resources and } \\
\text { people; our community, organizational and personal relationships; } \\
\text { and the quality of our products and services. (MarineEnergyl, } \\
\text { Website - Noel Upton) } \\
\text { - Our employees are in a sense missionaries. I mean, all of us are } \\
\text { dedicated to doing something new in the world and addressing the } \\
\text { issues of the need for energy in climate change with a new } \\
\text { technology. So it's exciting and enervating, you know, to be an } \\
\text { innovator and to be leading the world in something new... (Noel } \\
\text { Upton, Founder) }\end{array}$ & 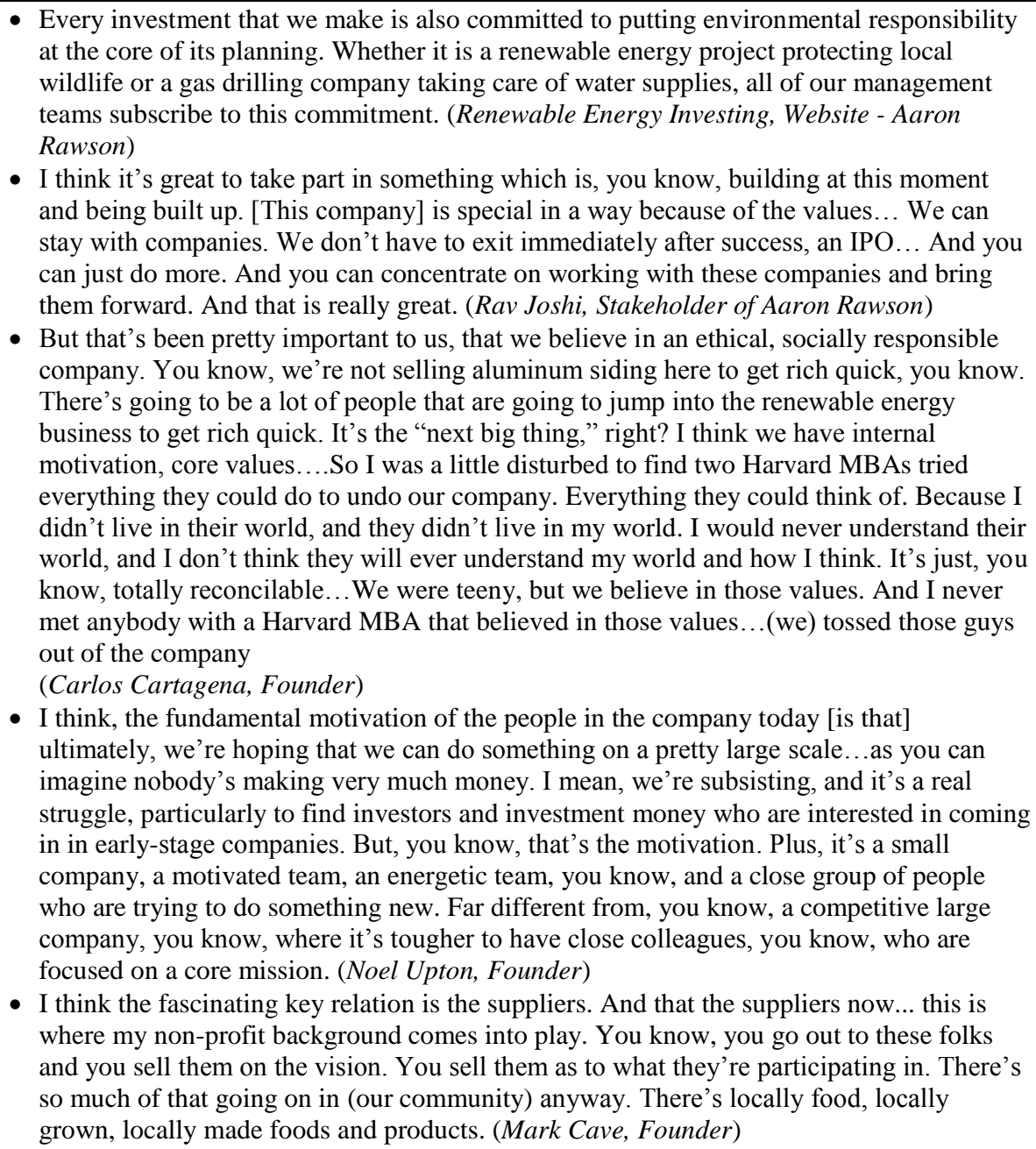 \\
\hline
\end{tabular}


FIGURE 1

A Model of Environmental Entrepreneurship
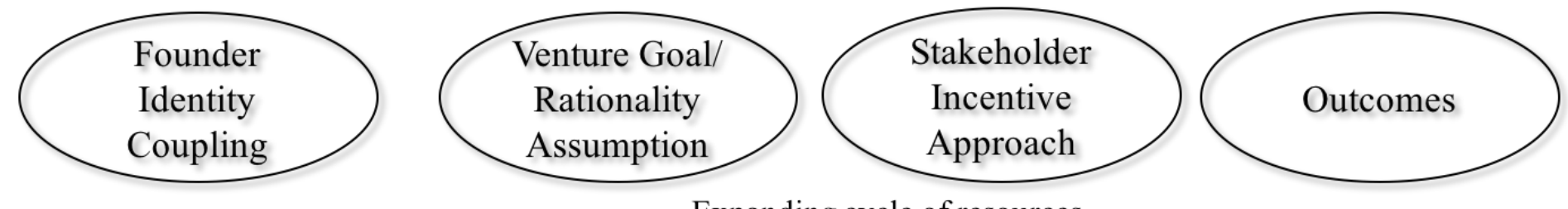

Expanding cycle of resources

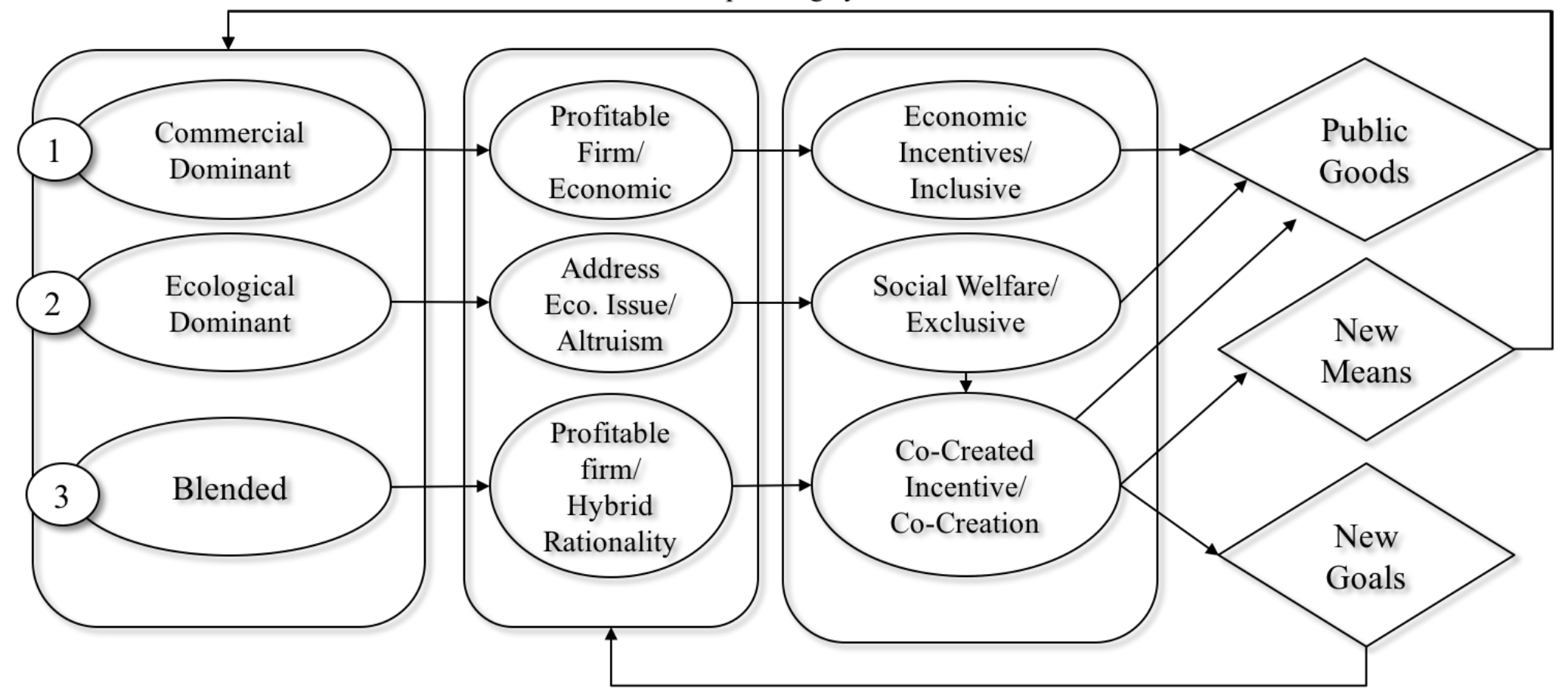

Converging cycle of goals 


\section{APPENDIX 1}

\section{Sample Founder Interview Protocol}

\section{Q.1 Background}

- Can you tell me about your background and how you came to start this company?

- Can you describe your work with the company from the founding to today? (What is your role in company?)

\section{Q.2 The Company and Founder}

- Can you tell me a story about the company from the founding to today? (A challenge you overcame? An important event in the founding process?)

- Could you describe the company's mission and strategy?

- What motivated you to start the company?

- What do you find most motivational about your work now?

\section{Q.3 Stakeholders}

- Can you tell me about how the company markets itself? (What message does the company use to create customer relationships?)

- How do you manage relationships that are important to the company's operations? (What message does the company communicate to communities, government, NGOs and suppliers?)

- Can you tell me about the investor relationships the company has? (What message does the company communicate to investors?)

- How does the company recruit and screen new employees? (How is the company portrayed to potential employees?)

- Does the company belong to trade associations? (If not, why not? If so, what benefit do you see?)

- Do you have ongoing relationships with competitors? (How does the company manage competitive relationships?)

- Are there other important relationships we didn't talk about?(How do you manage these?)

\section{Q.4 Institutional Climate}

- Some renewable energy companies say government incentives are important, while others say they are not; do they matter for your business model?

- Is the recent interest in environmentalism, epitomized by the phrase "going green" just a fad or does it represent something more significant? (What role do the media play in your business?) 